\title{
Influence of Deep Rolling and Induction Hardening on Microstructure Evolution of Crankshaft Sections made from 38MnSiVS5 and $42 \mathrm{CrMo4}$
}

\section{Einfluss des Festwalzens und des Induktionshärtens auf die Gefügeentwicklung am Beispiel von Kurbelwellen aus $38 \mathrm{MnSiVS5}$ und $42 \mathrm{CrMo} 4$}

In order to improve properties of complex automotive components, such as crankshafts, in an application-oriented way, several surface hardening treatments can be applied. Concerning the material performance the definition of adequate process parameters influences the resulting surface properties and, thus, the effectiveness of surface hardening treatments. To analyze most relevant process-microstructure-property relationships, the present paper reports results obtained by two different well-established surface hardening procedures, i. e. deep rolling as a mechanical treatment and induction hardening as a thermal treatment. For each hardening process widely used crankshaft steel grades, i. e. a medium carbon 38MnSiVS5 microalloyed steel and a quenched and tempered $42 \mathrm{CrMo} 4$ were selected and thoroughly characterized upon processing, using equal parameter settings. The results reveal that deep rolling in contrast to induction hardening proves to be a less sensitive surface layer treatment with regard to small differences in the initial microstructure, the chemical composition and the applied process parameters. Differences in microstructure evolution with respect to the applied surface hardening treatment are studied and discussed for the highly stressed fillet region of automotive crankshaft sections for all conditions. In this context, high-resolution SEM-based techniques such as EBSD and ECCI are proven to be very effective for fast qualitative evaluation of induced microstructural changes.

Keywords: Automotive industry, X-ray diffraction (XRD), deep rolling, induction hardening, medium carbon microalloyed steels, quenched and tempered steels
Um die Eigenschaften komplexer Automobilkomponenten wie zum Beispiel von Kurbelwellen zu verbessern, können verschiedene Oberflächenbehandlungsverfahren angewendet werden. Geeignet definierte Prozessparameter beeinflussen in Bezug auf die Materialperfomance die resultierenden Oberflächeneigenschaften und damit die Wirksamkeit von Oberflächenhärtungsbzw. Verfestigungsbehandlungen. Um die relevanten Beziehungen zwischen Prozess, Mikrostruktur und Eigenschaften zu analysieren, werden in der vorliegenden Arbeit die Ergebnisse des etablierten Festwalzens als mechanisches Behandlungsverfahren und des Induktionshärtens als rein thermische Behandlung detailliert beschrieben. Für jeden Prozess wurden Stahlsorten ausgewählt, die bei Kurbelwellen weit verbreitet sind, d. h. ein mikrolegierter 38MnSiVS5-Stahl mit mittlerem Kohlenstoffgehalt und ein vergüteter $42 \mathrm{CrMo} 4$. Diese wurden im Anschluss an die Prozessierung mit gleichen Parametern umfassend charakterisiert. Die Forschungsergebnisse zeigen dabei, dass sich das Festwalzen im Gegensatz zum Induktionshärten als weniger empfindlich auf geringe Unterschiede hinsichtlich des Ausgangsgefüges, der chemischen Zusammensetzung sowie der verwendeten Prozessparameter erweist. In Bezug auf Unterschiede in der Mikrostrukturentwicklung haben sich hochauflösende REM-basierte Untersuchungsmethoden unter Einbeziehung von EBSD und ECCI als sehr effektiv erwiesen, um eine schnelle qualitative Bewertung der induzierten Gefügeänderungen darzustellen.

Schlüsselwörter: Automobilindustrie, Röntgenbeugung, Festwalzen, Induktionshärten, mikrolegierter Stahl, Vergütungsstahl

Authors/Autoren: M. Sc. Andreas Fischer, Prof. a. D. Dr.-Ing. habil. Berthold Scholtes, Prof. Dr.-Ing. Thomas Niendorf, Institut für Werkstofftechnik (Materials Engineering), Universität Kassel, 34125 Kassel, niendorf@uni-kassel.de (Corresponding author/Kontakt)

HOW TO CITE THIS ARTICLE: A. Fischer et al.: Influence of Deep Rolling and Induction Hardening on Microstructure Evolution of Crankshaft Sections made from 38MnSiVS5 and 42CrMo4. HTM J. Heat Treatm. Mat. 76 (2021) 3, pp. 175-194, DOI:10.1515/htm-2021-0002 


\section{Introduction}

Due to more intense global competition, low-cost manufacturing has become one of the main objectives in the automotive industry [1]. In this context, recent automotive requirements with regard to material selection, surface hardening treatments, manufacturing processes and cost efficiency of high-performance components have to be reflected critically [2-4]. Especially the crankshaft is one of the main components of an engine that is subjected to cyclic loading [5]. Referring to application oriented needs, several surface hardening treatments such as deep rolling (mechanical treatment) and induction hardening (thermal treatment) are available, aiming at the reduction of wear and extension of fatigue lives of the crankshaft [6-9]. Material selection has a significant influence on the effect of established surface hardening techniques, e. g. on edge-near regions [3]. Thus, in light of industrial competition, the optimal material selection moves into focus and can no longer be neglected $[10,11]$.

High strength to weight ratio as well as good fracture toughness are fundamental issues for industrial application. However, steels are still the most economic option for critical components with regard to mechanical properties when fracture toughness is paramount [12]. In that sense, medium carbon microalloyed steels and quenched and tempered $(\mathrm{Q}+\mathrm{T})$ steels, such as $38 \mathrm{MnSiVS5}$ and $42 \mathrm{CrMo} 4$, respectively, represent good materials, which are widely used for various kinds of components under static as well as cyclic loading [13-15].

The main objective of the present paper is to evaluate microstructural differences in the surface area between a medium carbon $38 \mathrm{MnSiVS} 5$ microalloyed steel and a Q+T 42CrMo4 steel treated by established surface hardening techniques, i. e. deep rolling and induction hardening. Both steel grades were hardened employing equal parameter settings in case of each individual surface hardening technique. In consequence, comparisons between those two steel grades can be directly conducted in a meaningful way. Initial conditions are used as reference. Investigations were carried out on the highly stressed fillet region of the crankshaft. Differences in microstructure evolution were characterized by hardness profiling, X-ray diffraction measurements, supplemented with high-resolution electron microscopy. Electron backscatter diffraction (EBSD) and electron channeling contrast imaging (ECCI) were used for detailed analysis of local microstructural features and crystal defects, thus, providing in-depth understanding of elementary hardening mechanisms contributing to final properties in either condition. The results presented allow to draw solid material-process-microstructure-property relationships.

\section{Einleitung}

Aufgrund des verschärften globalen Wettbewerbs ist die kostengünstige Fertigung in der Automobilindustrie zu einem der Hauptziele geworden [1]. In diesem Zusammenhang müssen die aktuellen Anforderungen der Automobilindustrie in Bezug auf Materialauswahl, Oberflächenhärtung, Fertigungsprozesse und Kosteneffizienz von Hochleistungskomponenten kritisch reflektiert werden [2-4]. Insbesondere die Kurbelwelle ist eine der Hauptkomponenten eines Motors, die einer zyklischen Belastung ausgesetzt ist [5]. Entsprechend den anwendungsbezogenen Anforderungen stehen verschiedene Oberflächenhärtungsverfahren wie Festwalzen (mechanische Behandlung) und Induktionshärten (thermische Behandlung) zur Verfügung, die auf die Reduzierung des Verschleißes und die Verlängerung der Lebensdauer der Kurbelwelle abzielen [6-9]. Die Werkstoffauswahl hat einen wesentlichen Einfluss auf die Wirkung etablierter Oberflächenhärteverfahren z. B. auf kantennahe Bereiche [3]. Damit rückt die optimale Werkstoffauswahl angesichts des industriellen Wettbewerbs in den Fokus und kann nicht mehr vernachlässigt werden $[10,11]$.

Ein hohes Festigkeits-Gewichts-Verhältnis sowie eine gute Bruchzähigkeit sind für die industrielle Anwendung von grundlegender Bedeutung. Dennoch sind Stähle für kritische Bauteile hinsichtlich der mechanischen Eigenschaften immer noch die wirtschaftlich gesehen beste Option, wenn die Bruchzähigkeit im Vordergrund steht [12]. In diesem Sinne stellen mikrolegierte Stähle mit mittlerem Kohlenstoffgehalt und Vergütungsstähle $(\mathrm{Q}+\mathrm{T})$ wie $38 \mathrm{MnSiVS5}$ bzw. $42 \mathrm{CrMo} 4$ gute Optionen dar, die für verschiedene Arten von Bauteilen sowohl unter statischer als auch zyklischer Belastung weit verbreitet sind [13-15].

Das Hauptziel der vorliegenden Arbeit ist es, mikrostrukturelle Unterschiede im Oberflächenbereich zwischen einem mikrolegierten Stahl mit mittlerem Kohlenstoffgehalt (38MnSiVS5) und einem Q+T-Stahl (42CrMo4) zu bewerten, der mit etablierten Oberflächenhärtungsverfahren, d.h. Festwalzen und Induktionshärten, behandelt wurde. Beide Stahlsorten wurden jeweils unter gleichen Parametereinstellungen mit den beiden Oberflächenhärtungsverfahren gehärtet. Somit können Vergleiche zwischen diesen beiden Stahlsorten direkt und sinnvoll durchgeführt werden. Als Referenz werden die Ausgangsbedingungen verwendet. Die Untersuchungen wurden im hochbelasteten Kehlbereich der Kurbelwelle durchgeführt. Unterschiede in der Gefügeentwicklung wurden durch Härteprofilierung und Röntgenbeugungsmessungen ergänzt durch hochauflösende Elektronenmikroskopie charakterisiert. Elektronenrückstreuungsbeugung (EBSD) und Elektronenkontrastbildgebung (ECCI) wurden zur detaillierten Analyse lokaler Gefügemerkmale und Kristalldefekte verwendet und ermöglichten so ein tiefgehendes Verständnis der elementaren Härtungsmechanismen, die zu den endgültigen Eigenschaften in beiden Zuständen beitragen. Die vorgestellten Ergebnisse erlauben es, Schlüsse bezüglich der Material-Prozess-Mikrostruktur-Eigenschafts-Beziehungen zu ziehen. 


\section{Experimental Procedure}

\subsection{Material conditions and surface hardening parameters}

Investigations were carried out on individual crankshaft sections. A medium carbon 38MnSiVS5 microalloyed steel and a $\mathrm{Q}+\mathrm{T}$ $42 \mathrm{CrMo} 4$ steel were used, representing common steel grades for automotive components [3]. Information on corresponding continuous-cooling-transformation (CCT)-curves are presented in $[16,17]$. Steel grades were provided by Sidenor, Spain, and manufactured by forging. Detailed manufacturing parameters are intellectual property (IP) of the companies involved and, thus, cannot be disclosed. The chemical compositions of the final crankshaft sections made from the microalloyed 38MnSiVS5 and the quenched and tempered $42 \mathrm{CrMo} 4$ were determined with optical emission spectroscopy and are listed in Table 1.

Crankshaft sections were investigated in three different conditions: initial condition (for reference), deep rolled and induction hardened. In order to ensure a solid basis for all subsequent hardening treatments, all crankshafts were forged and subsequently machined by grinding (initial condition). Applied parameters for deep rolling and induction hardening were always kept constant for both steel grades.

Deep rolling was carried out by Hegenscheidt, Germany. For the deep rolling process at room temperature a force of $55 \mathrm{kN}$, a ball size radius of $3.4 \mathrm{~mm}$ and a rolling angle of $34.85^{\circ}$ were employed, resulting in a rolling force of $33.5 \mathrm{kN}$ in the fillet area. Each rolling cycle comprised a total of 13 runs. The deep rolling cycle began with five overrollings using a contact force of $0.3 \mathrm{kN}$. Afterwards, a linear increase up to the maximum force of $33.5 \mathrm{kN}$ was applied, where the maximum force was kept constant for five further overrollings. Within three final overrollings the force de-

\section{Experimenteller Ablauf}

\subsection{Materialbedingungen und Parameter der Oberflächenhärtung}

Die Untersuchungen wurden an einzelnen Kurbelwellenabschnitten durchgeführt. Es wurden ein mittelkohlenstoffhaltiger mikrolegierter Stahl 38MnSiVS5 und ein Q+T-Stahl 42CrMo4 verwendet, die gängige Stahlsorten für Automobilkomponenten darstellen [3]. Informationen zu den entsprechenden Continuous-CoolingTransformation (CCT)-Kurven sind in $[16,17]$ ausführlich beschrieben. Die Stahlsorten wurden von der Firma Sidenor aus Spanien zur Verfügung gestellt und durch Schmieden hergestellt. Die detaillierten Herstellungsparameter sind geistiges Eigentum der beteiligten Unternehmen und können daher nicht offengelegt werden. Die chemischen Zusammensetzungen der endgültigen Kurbelwellenabschnitte aus dem mikrolegierten 38MnSiVS5 und dem vergüteten $42 \mathrm{CrMo} 4$ wurden mit optischer Emissionsspektroskopie bestimmt und sind in Tabelle 1 aufgeführt.

Die Kurbelwellenabschnitte wurden in drei verschiedenen $\mathrm{Zu}$ ständen untersucht: Ausgangszustand (als Referenz), tiefgewalzt und induktionsgehärtet. Um eine solide Basis für alle nachfolgenden Härtebehandlungen zu gewährleisten, wurden alle Kurbelwellen geschmiedet und anschließend durch Schleifen bearbeitet (Ausgangszustand). Die angewandten Parameter für das Festwalzen und Induktionshärten wurden für beide Stahlsorten stets konstant gehalten.

Das Festwalzen wurde von Hegenscheidt aus Deutschland durchgeführt. Für den Festwalzprozess bei Raumtemperatur wurden eine Kraft von $55 \mathrm{kN}$, ein Kugelradius von 3,4 mm und ein Walzwinkel von $34,85^{\circ}$ verwendet, woraus sich eine Walzkraft von $33,5 \mathrm{kN}$ im Kehlbereich ergab. Jeder Walzzyklus umfasste insgesamt 13 Durchläufe. Der Festwalzzyklus beginnt mit fünf Überrollungen mit einer Anpresskraft von 0,3 kN. Danach erfolgt ein linearer Anstieg bis zur Maximalkraft von $33,5 \mathrm{kN}$, wobei die Maximalkraft für fünf weitere Überrollungen konstant gehalten

\begin{tabular}{|c|c|c|c|c|c|c|c|}
\hline \multicolumn{8}{|c|}{ 38MnSiVS5 (1.5231) } \\
\hline $\mathrm{C}$ & $\mathrm{Si}$ & Mn & $P$ & $S$ & $\mathrm{Cr}$ & Mo & $\mathrm{Ni}$ \\
\hline 0.37 & 0.61 & 1.41 & 0.02 & 0.05 & 0.11 & 0.01 & 0.08 \\
\hline $\mathrm{Cu}$ & $\mathrm{Al}$ & $\mathrm{Ti}$ & $\mathrm{Nb}$ & $\mathrm{V}$ & W & Co & \\
\hline 0.15 & 0.01 & $<0.01$ & $<0.01$ & 0.12 & 0.06 & 0.01 & \\
\hline \multicolumn{8}{|c|}{ 42CrMo4 (1.7225) } \\
\hline $\mathrm{C}$ & $\mathrm{Si}$ & $\mathrm{Mn}$ & $\mathbf{P}$ & $S$ & $\mathrm{Cr}$ & Mo & $\mathrm{Ni}$ \\
\hline 0.42 & 0.3 & 0.73 & 0.01 & 0.03 & 1.16 & 0.17 & 0.09 \\
\hline $\mathrm{Cu}$ & $\mathrm{Al}$ & $\mathrm{Ti}$ & $\mathrm{Nb}$ & $\mathrm{V}$ & $\mathrm{W}$ & Co & \\
\hline 0.12 & 0.02 & $<0.01$ & $<0.01$ & $<0.01$ & $<0.01$ & $<0.01$ & \\
\hline
\end{tabular}

Table 1. Chemical composition of the medium carbon $38 \mathrm{MnSiVS5}$ microalloyed steel (1.5231) and the quenched and tempered $(\mathrm{Q}+\mathrm{T})$ $42 \mathrm{CrMo4}$ steel (1.7225) in wt.-\%

Tabelle 1. Chemische Zusammensetzung eines mikrolegierten Stahls mit mittlerem Kohlenstoffgehalt 38MnSiVS5 (1.5231) sowie eines vergüteten $(\mathrm{Q}+\mathrm{T})$ Stahls $42 \mathrm{CrMo4}$ (1.7225) in Gew.-\% 
creased linearly to a contact force of $0.3 \mathrm{kN}$. No forced cooling was applied due to the slow process speed and the localized load impact. For this reason, high temperatures during the mechanical treatment can be neglected.

The induction hardening process was conducted by Comforsa, Spain, using an induction power of $80 \mathrm{~kW}$. The respective holding times at the austenitization level as well as the quenching rates are IP of Comforsa. For this reason these parameters cannot be provided. The quenching process was conducted using a quenching fluid consisting of water and $10 \%$ Aquaquench $^{\oplus}$ (polymer). For the quenching process a temperature of $30^{\circ} \mathrm{C}$ was used.

\subsection{Measurement procedures and parameters of crankshaft sections}

The area of interest (AoI) of the crankshaft section is illustrated in Figure 1a and highlighted by the black circle. The final sample geometry applied for hardness testing, XRD characterization and microscopy was obtained by wire-cut electro discharge machining $(\mathrm{EDM})$, which was used to prevent a significant redistribution of the residual stresses in the vicinity of the fillet area. Detailed information with regard to the preparation of the crankshaft sections can be taken from a previous investigation [6]. Hardness profiles and X-ray diffraction measurements (residual stress and integral width) were conducted along five measuring directions on the cross section as detailed in Figure 1b. X-ray diffraction measurements were performed in the tangential direction to the surface of the crankshaft fillet. In light of the present investigations, the same measuring procedure was employed in order to ensure comparability. The number of measurement points needed for each measuring angle $\left(-30^{\circ}\right.$ to $30^{\circ}$ in Fig. 1b) depended on the applied surface hardening treatment, i. e. deep rolling and induction hardening. Furthermore, EBSD and ECCI characterization was conducted within the AoI as defined in Figure 1a. The exact locations are given in Figures 7 and 8.

\subsubsection{Hardness measurements}

For hardness testing specimens were ground and polished. Hardness measurements were carried out according to Vickers HV 0.5

Fig. 1. (a) Aol for all samples (black circle), (b) detailed view on the Aol, including respective dimensions and defined directions, recompiled from [6]

Bild 1. (a) Aol für alle Proben (schwarzer Kreis), (b) Detailansicht der Aol, einschließlich der jeweiligen Abmessungen und definierten Messrichtungen, neu zusammengestellt aus [6] wird. Bei den letzten drei Überrollungen sinkt die Kraft linear auf eine Anpresskraft von 0,3 kN ab. Aufgrund der langsamen Prozessgeschwindigkeit und der lokalen Lasteinwirkung wurde keine Zwangskühlung durchgeführt. Aus diesem Grund können hohe Temperaturen während der mechanischen Behandlung vernachlässigt werden.

Der Induktionshärteprozess wurde von Comforsa aus Spanien mit einer Induktionsleistung von $80 \mathrm{~kW}$ durchgeführt. Die jeweiligen Haltezeiten in der Austenitisierungsstufe sowie die Abschreckraten sind IP von Comforsa. Aus diesem Grund können diese Parameter nicht angegeben werden. Der anschließende Abschreckprozess wurde mit einer Abschreckflüssigkeit, bestehend aus Wasser und $10 \%$ Aquaquench ${ }^{\circledR}$ (Polymer), durchgeführt. Für den Quenchvorgang wurde eine Temperatur von $30^{\circ} \mathrm{C}$ verwendet.

\subsection{Messverfahren und Parameter von Kurbelwellenabschnitten}

Der Bereich von Interesse (AoI) des Kurbelwellenabschnitts ist in Bild 1a) dargestellt und durch den schwarzen Kreis hervorgehoben. Die endgültige Probengeometrie, die für die Härteprüfung, die XRDCharakterisierung und die Mikroskopie verwendet wurde, wurde durch Drahterodieren (EDM) hergestellt, um eine signifikante Umverteilung der Eigenspannungen in der Nähe des Verrundungsbereichs zu verhindern. Detaillierte Informationen zur Präparation der Kurbelwellenabschnitte können einer früheren Untersuchung entnommen werden [6]. Härteprofile und Röntgenbeugungsmessungen (Eigenspannung und Integralbreite) wurden entlang von fünf Messrichtungen am Querschnitt durchgeführt, wie in Bild $1 \mathrm{~b}$ dargestellt. Die Röntgenbeugungsmessungen wurden in tangentialer Richtung zur Oberfläche der Kurbelwellenverrundung durchgeführt. Für die vorliegenden Untersuchungen wurde das gleiche Messverfahren verwendet, um eine gute Vergleichbarkeit zu gewährleisten. Die Anzahl der Messpunkte, die für jeden Messwinkel $\left(-30^{\circ}\right.$ bis $30^{\circ}$ in Bild $\left.1 \mathrm{~b}\right)$ benötigt wurden, hing von der angewandten Oberflächenhärtungsbehandlung Festwalzen und Induktionshärten ab. Darüber hinaus wurde die EBSD- und ECCI-Charakterisierung innerhalb der in Bild 1a definierten AoI durchgeführt. Die genauen Orte sind in Bild 7 und 8 angegeben.

\subsubsection{Härtemessungen}

Für die Härteprüfung wurden die Proben geschliffen und poliert. Die Härtemessungen erfolgten nach Vickers HV 0,5 (Prüfkraft von
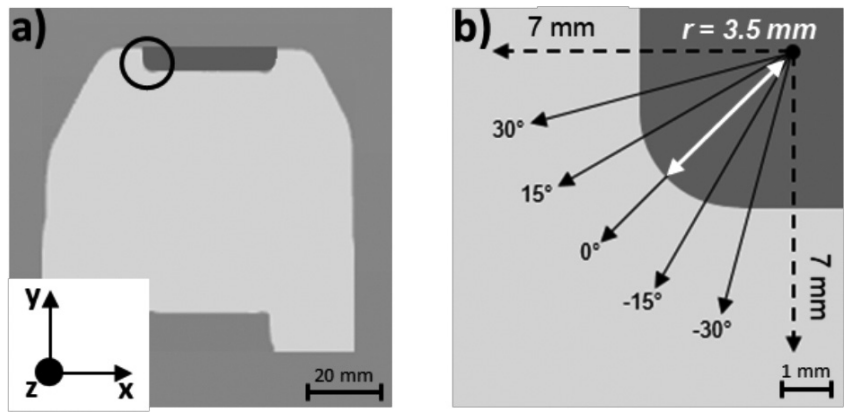
(testing load of $4.903 \mathrm{~N}$ ) alongside five directions as given in Figure $1 \mathrm{~b}$ using a Struers DuraScan 70 system. The distance between single indents as well as the distance from the edge was set to $0.25 \mathrm{~mm}$ in line with the relevant standard [18]. Hardness measurement values are characterized by a scatter of $\pm 8 \mathrm{HV} 0.5$. In addition to the hardness measurements alongside the displayed angles (Fig. 1b) a full-field hardness measurement was carried out for the induction hardened condition in order to reveal more information about the fillet region. Based on the crankshaft fillet radius of $3.5 \mathrm{~mm}$, an adequate area of $7 \mathrm{~mm} \times 7 \mathrm{~mm}$ was defined as AoI for hardness mapping (detailed in Fig. 1b). Each hardness map consists of 660 indentations.

\subsubsection{X-ray diffraction measurements}

X-ray diffraction measurements were carried out using a diffractometer D 5000 equipped with a Cr tube source operating at $35 \mathrm{kV}$ and $30 \mathrm{~mA}$. Furthermore, a monocapillary of $0.3 \mathrm{~mm}$ in diameter was used. The diffracted intensity was obtained on the basis of the (211) plane of the ferrite from $148^{\circ}$ to $164^{\circ}$. Within this range a step size of $0.1^{\circ}$ and a counting time of $2 \mathrm{~s}$ (per step) were used. For stress analysis 11 equidistant $\Psi$ angles between $-45^{\circ}-45^{\circ}$ were evaluated according to the classical $\sin ^{2}-\Psi$ method. Following the settings detailed for the hardness measurements, the distance between locations for X-ray diffraction measurements was set to $0.25 \mathrm{~mm}$. In-depth measurements were performed by using material removal applying electropolishing. Detailed information with regard to the procedure can be taken from [6]. X-ray diffraction measurement values are characterized by a scatter of $\pm 20 \mathrm{MPa}$. Redistribution and minor relaxation of the initial residual stress profile can occur due to the removal of stressed material [19]. For the stepwise removal method, residual stress corrections are often negligible, especially when stresses are not used for further fatigue property calculations or when sufficiently small removal volumes are considered [4]. For this reason, corrections were not carried out for the thin removed layers in present work.

\subsubsection{High-resolution electron microscopy (EBSD and ECCI measurements)}

Electron backscatter diffraction (EBSD) and electron channeling contrast imaging (ECCI) measurements were carried out within the AoI as defined in Figure 1a. For both kinds of investigations a Zeiss Ultra Plus scanning electron microscope (SEM) equipped with a field emission gun was used. The surface finish being required to allow EBSD and ECCI investigations was obtained by mechanical grinding, polishing and subsequent vibratory polishing using a colloidal sillica solution of $0.04 \mu \mathrm{m}$ for about 48 hours.

For EBSD measurements, an acceleration voltage of $20 \mathrm{kV}$ and high beam current were applied while using a Bruker e-Flash ${ }^{\text {HR }}$
4,903 N) entlang von fünf Richtungen gemäß Bild 1b mit einem Struers DuraScan 70 System. Der Abstand zwischen den einzelnen Eindrücken sowie der Abstand vom Rand wurden entsprechend der einschlägigen Norm [18] auf 0,25 mm eingestellt. Die Härtemesswerte sind durch eine Streuung von \pm 8 HV 0,5 gekennzeichnet. Zusätzlich zu den Härtemessungen entlang der dargestellten Winkel (Bild 1b) wurde eine Vollfeldhärtemessung für den induktiv gehärteten Zustand durchgeführt, um mehr Informationen über den Verrundungsbereich $\mathrm{zu}$ erhalten. Basierend auf dem Kurbelwellenverrundungsradius von 3,5 mm wurde ein ausreichender Bereich von $7 \mathrm{~mm} \times 7 \mathrm{~mm}$ als AoI für die Härtekartierung definiert (detailliert in Bild 1b). Jede Härtekarte besteht aus 660 Vertiefungen.

\subsubsection{Röntgenbeugungsmessungen}

Die Röntgenbeugungsmessungen wurden mit einem Diffraktometer D 5000 durchgeführt, das mit einer Cr-Röhrenquelle ausgestattet war, die bei $35 \mathrm{kV}$ und $30 \mathrm{~mA}$ arbeitete. Außerdem wurde eine Monokapillare mit einem Durchmesser von $0,3 \mathrm{~mm}$ verwendet. Die Beugungsintensität wurde auf der Basis der (211)-Ebene des Ferrits von $148^{\circ}$ bis $164^{\circ}$ ermittelt. Innerhalb dieses Bereichs wurde eine Schrittweite von $0,1^{\circ}$ und eine Zählzeit von $2 \mathrm{~s}$ (pro Schritt) verwendet. Zur Spannungsanalyse wurden 11 äquidistante $\Psi$-Winkel zwischen $-45^{\circ}-45^{\circ}$ nach der klassischen $\sin ^{2}-\Psi$ Methode ausgewertet. In Anlehnung an die für die Härtemessungen beschriebenen Einstellungen wurde der Abstand zwischen den Messorten für die Röntgenbeugungsmessungen auf 0,25 mm festgelegt. Tiefenmessungen wurden durch Materialabtrag mittels Elektropolieren durchgeführt. Detaillierte Informationen zur Vorgehensweise können aus [6] entnommen werden. Die Röntgenbeugungsmesswerte sind durch eine Streuung von $\pm 20 \mathrm{MPa}$ gekennzeichnet. Durch den Abtrag von belastetem Material kann es $\mathrm{zu}$ einer Umverteilung sowie einer geringen Relaxation des ursprünglichen Eigenspannungsprofils kommen [19]. Bei der schrittweisen Abtragsmethode sind Eigenspannungskorrekturen oft vernachlässigbar, insbesondere wenn die Spannungen nicht für weitere Berechnungen der Ermüdungseigenschaften verwendet werden, ebenso wie bei ausreichend kleinem Abtragsvolumen [4]. Aus diesem Grund wurden in der vorliegenden Arbeit keine Korrekturen für die dünnen abgetragenen Schichten durchgeführt.

\subsubsection{Hochauflösende Elektronenmikroskopie (EBSD- und ECCI-Messungen)}

Elektronenrückstreuungsbeugung (EBSD) und Elektronenkontrastmessungen (ECCI) wurden innerhalb der in Bild la definierten AoI durchgeführt. Für beide Arten von Untersuchungen wurde ein Zeiss Ultra Plus Rasterelektronenmikroskop (SEM) mit einer Feldemissionskanone verwendet. Die für EBSD- und ECCIUntersuchungen erforderliche Oberflächengüte wurde durch mechanisches Schleifen, Polieren und anschließendes Vibrationspolieren mit einer kolloidalen Glimmerlösung von 0,04 $\mu \mathrm{m}$ für etwa 48 Stunden erreicht.

Für die EBSD-Messungen wurden eine Beschleunigungsspannung von $20 \mathrm{kV}$ und ein hoher Strahlstrom angewandt, wo- 
detector with a maximum resolution of $1600 \times 1200$ pixel. In order to reduce measurement time, a binning mode of $160 \times 120$ pixel was used. Investigations were carried out by using an inclination of the detector of approx. $3.9^{\circ}$ and an inclination of the sample holder of $70^{\circ}$. The working distance was set to $16.5 \mathrm{~mm}$. In case of the coarse-grained microstructure in the initial and deep rolled condition, a step size of $0.2 \mathrm{~mm}$ was used, whereas a step size of $0.1 \mathrm{~mm}$ was applied for the induction hardened fillet area due to the very fine-grained microstructure. As detailed in Figures 7 and 8 , scans were carried out in the edge region of the fillet area. Post-processing of EBSD data was conducted by TSL OIM 7 Analysis including an analysis of texture and local orientation distribution, respectively. In this context, orientation image maps (OIM) as well as kernel average misorientation (KAM) maps were calculated for the different material conditions. The OIM maps were colored based on the standard triangle as detailed in Figure 7. Local misorientation is evaluated from the KAM. In order to obtain detailed information on the orientation differences within single grains, the average misorientation between a pixel $i$ and its first neighbour was analyzed. Furthermore, a threshold of $<5^{\circ}$ was defined. In this way misinterpretation due to the presence of low-angle grain boundaries can be avoided. Based on this procedure local plastic strain gradients were analyzed from KAM maps.

ECCI measurements were carried out using the same ZEISS Ultra Plus SEM at an acceleration voltage of $30 \mathrm{kV}$ and high beam current. ECCI provides microstructure related contrast as the intensity of backscattered electrons is strongly dependent on the orientation of the incident beam relative to the crystal planes. Thus, slight local distortions (induced by dislocations) in the crystal lattice lead to a modulation of the backscattered electron intensity. Induced by the biased backscattered electron yield in strained regions of a crystal, light-dark contrasts enable imaging of near-surface crystal defects.

\section{Results}

\subsection{Hardness, microstructure and $\mathrm{X}$-ray diffraction measurements*}

Figure 2 depicts representative hardness profiles for the initial, the deep-rolled and the induction hardened conditions of the fillet areas in medium carbon 38MnSiVS5 microalloyed steel $(\mathrm{a}, \mathrm{c}, \mathrm{e})$ and $\mathrm{Q}+\mathrm{T}$ $42 \mathrm{CrMo} 4$ steel (b, d, f). As illustrated for the initial condition in Figsures $2 a$ and $b$ the hardness values in the fillet region is constant. The mean average hardness of the $42 \mathrm{CrMo} 4$ ( $286 \mathrm{HV} 0.5$ ) slightly exceeds the mean average hardness state of the 38MnSiVS5 (270.7 HV 0.5). bei ein Bruker e-Flash ${ }^{\mathrm{HR}}$-Detektor mit einer maximalen Auflösung von $1600 \times 1200$ Pixel verwendet wurde. Um die Messzeit $\mathrm{zu}$ reduzieren, wurde ein Binning-Modus von $160 \times 120$ Pixel verwendet. Die Untersuchungen wurden unter Verwendung einer Neigung des Detektors von ca. $3,9^{\circ}$ und einer Neigung des Probenhalters von $70^{\circ}$ durchgeführt. Der Arbeitsabstand wurde auf 16,5 mm eingestellt. Im Falle des grobkörnigen Gefüges im Ausgangs- und Festwalzzustand wurde eine Schrittweite von $0,2 \mathrm{~mm}$ verwendet, während für den induktionsgehärteten Kehlbereich aufgrund seines sehr feinkörnigen Gefüges eine Schrittweite von $0,1 \mu \mathrm{m}$ angewendet wurde. Wie in Bild 7 und 8 dargestellt, wurden die Scans im Randbereich des Verrundungsbereichs durchgeführt. Die Nachbearbeitung der EBSD-Daten wurde mit TSL OIM 7 Analysis $7 \times 64$ durchgeführt, einschließlich der Analyse der Textur bzw. der lokalen Orientierungsverteilung. In diesem Zusammenhang wurden Orientation Image Maps (OIM) sowie Kernel Average Misorientation (KAM) Maps für die verschiedenen Materialzustände berechnet. Die OIM-Karten wurden auf der Grundlage des Standarddreiecks eingefärbt, wie in Bild 7 dargestellt. Die lokale Fehlorientierung wird aus dem KAM ausgewertet. Um detaillierte Informationen über die Orientierungsunterschiede innerhalb einzelner Körner zu erhalten, wurde die durchschnittliche Fehlorientierung zwischen einem Pixel i und seinem ersten Nachbarn ausgewertet. Weiterhin wurde ein Schwellenwert von $<5^{\circ}$ definiert. Auf diese Weise können Fehlinterpretationen durch das Vorhandensein von winkelarmen Korngrenzen vermieden werden. Basierend auf diesem Verfahren wurden lokale plastische Dehnungsgradienten aus KAMKarten analysiert.

ECCI-Messungen wurden mit demselben ZEISS Ultra Plus SEM bei einer Beschleunigungsspannung von $30 \mathrm{kV}$ und hohem Strahlstrom durchgeführt. ECCI liefert einen mikrostrukturbezogenen Kontrast, da die Intensität der rückgestreuten Elektronen stark von der Orientierung des einfallenden Strahls relativ zu den Kristallebenen abhängig ist. So führen leichte lokale Verzerrungen (induziert durch Versetzungen) im Kristallgitter zu einer Modulation der Intensität der rückgestreuten Elektronen. Induziert durch die verzerrte Rückstreuelektronenausbeute in verspannten Regionen eines Kristalls ermöglichen Hell-Dunkel-Kontraste das Abbilden von oberflächennahen Kristalldefekten.

\section{Ergebnisse}

\subsection{Härte-, Gefüge- und Röntgen- beugungsmessungen*}

Bild 2 zeigt repräsentative Härteprofile für den Ausgangszustand, den tiefgewalzten und den induktionsgehärteten Zustand der Verrundungsbereiche in mikrolegiertem Stahl mit mittlerem Kohlenstoffgehalt 38MnSiVS5 (a, c, e) und Q+T-Stahl 42CrMo4 (b, d, f). Wie für den Ausgangszustand in Bild 2a und b dargestellt, sind die Härtewerte im Verrundungsbereich konstant. Die mittlere Durchschnittshärte des Stahls 42CrMo4 $(286$ HV 0,5) übersteigt leicht 
Results displayed in Figures $2 \mathrm{c}$ and d reveal that the deep rolling process promoted to an almost uniform hardness ditribution in the fillet region. In contrast to the $\mathrm{Q}+\mathrm{T}$ steel, the medium carbon microalloyed steel shows a higher increase of hardness values in the vicinity of the surface layer. In both cases the increased hardness values decrease gradually to the initial values. The mean average hardness levels increased to $308 \mathrm{HV} 0.5$ (38MnSiVS5) and 306 HV 0.5 (42CrMo4).

Hardness distributions as a result of the induction hardening process are shown in Figures 2e and f. From a direct comparison of the induction hardened fillet areas of the 38MnSiVS5 and $42 \mathrm{CrMo} 4$, it can be deduced that the hardness profile in the fillet region for the $38 \mathrm{MnSiVS} 5$ is less homogeneous than for the $42 \mathrm{CrMo} 4$. In particular, the upper part of the fillet $\left(15^{\circ}\right.$ and $\left.30^{\circ}\right)$ in Figure 2e reveals a higher hardness level as compared to the hardness values near the running surface. This effect could not be found in case of the $42 \mathrm{CrMo} 4$. Moreover, hardness values alongside all measurement directions stay on constant levels in case of the Q+T steel, while hardness values steadily decline at depth values of up to $2.25 \mathrm{~mm}$ in 38MnSiVS5. Afterwards, hardness levels decrease more rapidly, however, an abrupt hardness drop can only den mittleren Durchschnittshärtezustand des Stahls 38MnSiVS5 (270,7 HV 0,5).

Die in Bild $2 c$ und d dargestellten Ergebnisse zeigen, dass der Festwalzprozess zu einer nahezu gleichmäßigen Härteverteilung im Kehlbereich geführt hat. Im Gegensatz zum Q+T-Stahl zeigt der mikrolegierte Stahl mit mittlerem Kohlenstoffgehalt einen stärkeren Anstieg der Härtewerte in der Nähe der Randschicht. In beiden Fällen gehen die erhöhten Härtewerte allmählich auf die Ausgangswerte zurück. Die mittleren Durschnittshärtewerte stiegen auf 308 HV 0,5 (38MnSiVS5) und 306 HV 0,5 (42CrMo4).

Die Härteverteilungen als Ergebnis des Induktionshärteprozesses sind in Bild 2e und f dargestellt. Aus dem direkten Vergleich der induktionsgehärteten Verrundungsbereiche von 38MnSiVS5 und 42CrMo4 lässt sich ableiten, dass das Härteprofil im Verrundungsbereich für $38 \mathrm{MnSiVS5}$ weniger homogen ist als für 42CrMo4. Insbesondere der obere Teil der Verrundung $\left(15^{\circ}\right.$ und $30^{\circ}$ ) in Bild 2e zeigt ein höheres Härteniveau im Vergleich zu den Härtewerten nahe der Lauffläche. Dieser Effekt konnte bei der 42CrMo4 nicht nachgewiesen werden. Außerdem bleiben die Härtewerte entlang aller Messrichtungen beim Q+T-Stahl auf konstantem Niveau, während die Härtewerte beim $38 \mathrm{MnSiVS5}$ bis zu einer Tiefe von 2,25 mm stetig abnehmen. Danach nehmen die Härtewerte schneller ab, ein abrupter Härteabfall ist jedoch nur

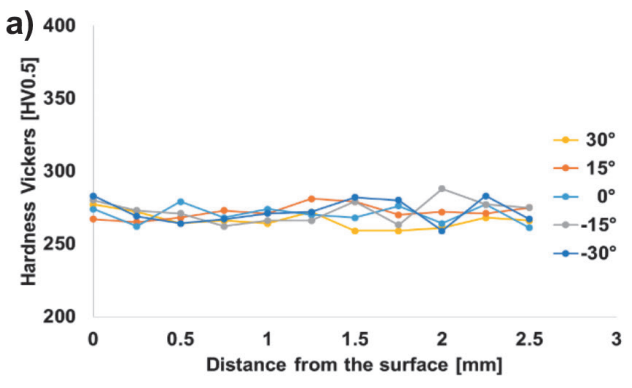

c) 400

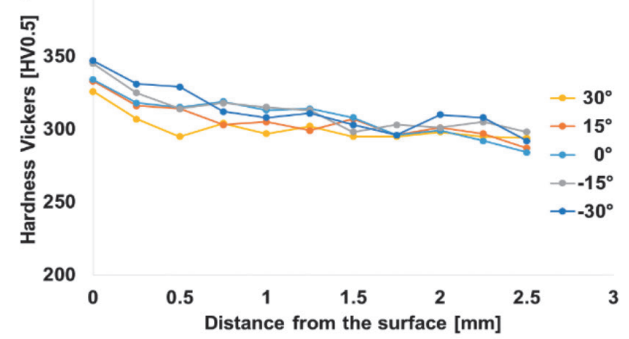

e) 700

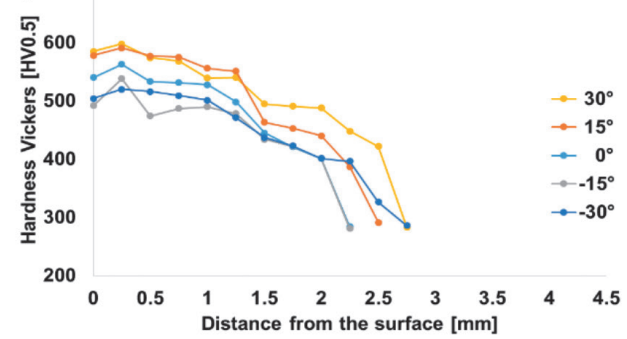

b) 400

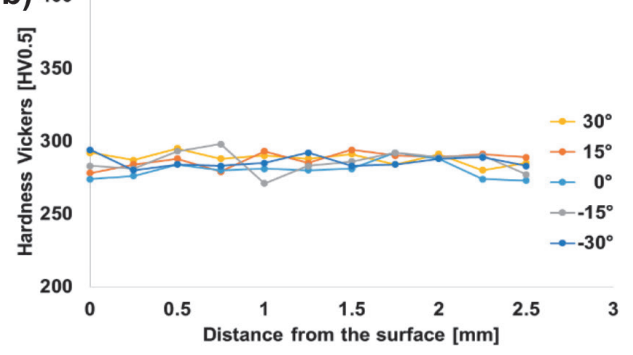

d) 400

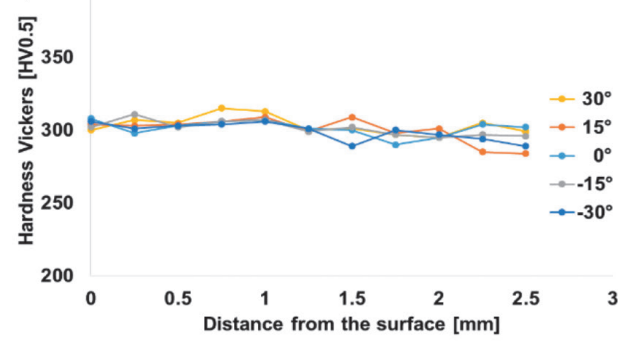

f) 700

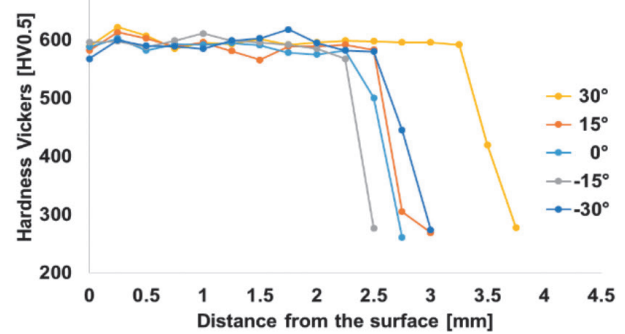

Fig. 2. Hardness distribution of the initial condition: a) 38MnSiVS5,

b) $42 \mathrm{CrMo4}$; deep rolled fillet area: c) $38 \mathrm{MnSiVS5}$, d) $42 \mathrm{CrMo} 4$; induction hardened fillet area: e) $38 \mathrm{MnSiVS5}$, f) $42 \mathrm{CrMo} 4$

Bild 2. Härteverteilung des Ausgangszustandes: a) 38MnSiVS5, b) $42 \mathrm{CrMo4}$; des festgewalzten Hohlkehlenbereiches:

c) $38 \mathrm{MnSiVS5}$, d) $42 \mathrm{CrMo4}$; des induktionsgehärteten Kehlbereich: e) $38 \mathrm{MnSiVS5}$, f) $42 \mathrm{CrMo} 4$

\footnotetext{
* Data presented and discussed in sects. 3.1 and 3.2 are partly taken from deliverable D1.2 "Report on characteristics of surface hardened layers produced by IH and DR" being part of a research action funded by RFCS (see "Acknowledgements" for details).
} 
be observed for the $42 \mathrm{CrMo4}$. Regardless of the measurement angle and the steel grade considered, maximum hardness values are found at a distance of $0.25 \mathrm{~mm}$ from the surface. Differences in the resulting penetration depths after induction hardening of $38 \mathrm{MnSiVS} 5$ and $42 \mathrm{CrMo} 4$ will be discussed in more detail after microstructural analysis of distinct areas within the crankshaft fillets.

The hardness map for a $38 \mathrm{MnSiVS} 5$ crankshaft section in the fillet region and the related scale bar are given in Figure 3. Induced by induction hardening, a maximum hardness of $618 \mathrm{HV} 0.5$ and a minimum hardness of $267 \mathrm{HV} 0.5$ were obtained in the fillet region. Figure 3 clearly highlights that the induction hardening process does not lead to a uniform hardness distribution over the entire fillet region. Highest hardness values are seen in areas (1) (in the upper fillet area) and (2) (near the running surface) at a distance of approx. $0.5 \mathrm{~mm}$ from the surface. In these areas, a fine-grained microstructure, predominantly composed of martensite, is present. Slight differences in grain size are observed between areas (1) and (2). Furthermore, a steep decrease of the hardness value of about $100 \mathrm{HV} 0.5$ within the area labelled (3) is identified. In this context, microstructure analysis reveals a sudden coarsening of the prevailing microstructure. Martensitically transformed areas appear absent. In area (4) the initial coarsegrained ferritic-pearlitic microstructure is identified where hardness values approach the average hardness of the initial condition.

In Figure 4 the full-field hardness distribution for a $42 \mathrm{CrMo} 4$ crankshaft fillet region is shown. As a result of induction hardening a maximum hardness of $663 \mathrm{HV} 0.5$ and a minimum hardness of $265 \mathrm{HV} 0.5$ were obtained in the fillet area. In fact, the hardness distribution for the 42CrMo4 (Fig. 4) seems to be more uniform than for the 38MnSiVS5 (Fig. 3). Highest hardness values were measured in direct vicinity of the surface (approx. $0.5 \mathrm{~mm}$ from the beim $42 \mathrm{CrMo} 4$ zu beobachten. Unabhängig vom Messwinkel und der betrachteten Stahlsorte werden maximale Härtewerte in einem Abstand von 0,25 mm zur Oberfläche gefunden. Unterschiede in den resultierenden Eindringtiefen nach dem Induktionshärten von 38MnSiVS5 und 42CrMo4 werden nach Gefügeanalysen von bestimmten Bereichen innerhalb der Kurbelwellenverrundungen genauer diskutiert.

Die Härtekarte für einen 38MnSiVS5-Kurbelwellenabschnitt im Verrundungsbereich und der zugehörige Maßstabsbalken sind in Bild 3 dargestellt. Durch die Induktionshärtung wurden im Verrundungsbereich eine maximale Härte von $618 \mathrm{HV} 0,5$ und eine minimale Härte von 267 HV 0,5 erreicht. Bild 3 zeigt deutlich, dass der Induktionshärteprozess nicht zu einer gleichmäßigen Härteverteilung über den gesamten Verrundungsbereich führt. Die höchsten Härtewerte zeigen sich in den Bereichen (1) (im oberen Verrundungsbereich) und (2) (nahe der Lauffläche) in einem Abstand von ca. 0,5 mm zur Oberfläche. In diesen Bereichen ist ein feinkörniges Gefüge vorhanden, das überwiegend aus Martensit besteht. Leichte Unterschiede in der Korngröße werden zwischen den Bereichen (1) und (2) beobachtet. Des Weiteren ist ein steiler Abfall des Härtewertes von etwa 100 HV 0,5 innerhalb des mit (3) bezeichneten Bereiches zu erkennen. In diesem Zusammenhang zeigt die Gefügeanalyse eine plötzliche Vergröberung des vorherrschenden Gefüges. Martensitisch umgewandelte Bereiche scheinen jedoch nicht vorhanden zu sein. Im Bereich (4) wird das anfänglich grobkörnige ferritisch-perlitische Gefüge identifiziert, dessen Härtewerte sich der mittleren Härte des Ausgangszustandes annähern.

In Bild 4 ist die Vollfeld-Härteverteilung für einen 42CrMo4Kurbelwellenverrundungsbereich zu sehen. Als Ergebnis der Induktionshärtung wurden im Verrundungsbereich eine maximale Härte von 663 HV 0,5 und eine minimale Härte von 265 HV 0,5 erreicht. Tatsächlich scheint die Härteverteilung für das 42CrMo4 (Bild 4) gleichmäßiger zu sein als für das 38MnSiVS5 (Bild 3). Die höchsten Härtewerte wurden in unmittelbarer Nähe der Oberflä-

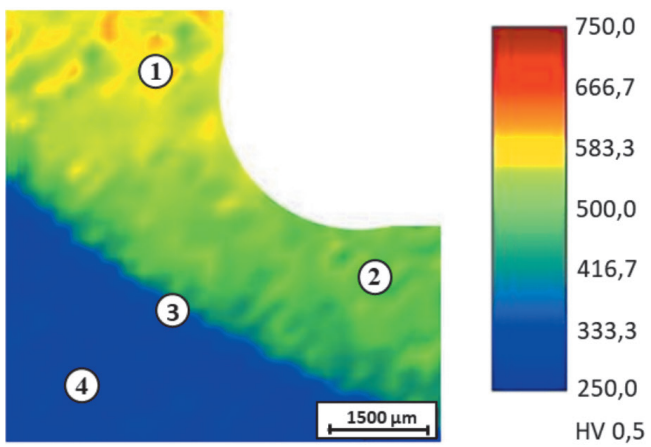

Fig. 3. Hardness distribution map of the induction hardened crankshaft fillet of the $38 \mathrm{MnSiVS} 5$ as well as microstructural sections: (1) in the upper fillet area, (2) near the running surface, (3) in the transition area and (4) below the transition area (labeling in German)

Bild 3. Härtemapping der induktionsgehärteten Hohlkehle des 38MnSiVS5 sowie Gefügeanschliffe: (1) im oberen Hohlkehlenbereich, (2) in der Nähe der Lauffläche, (3) im Übergangsbereich und (4) nach dem Übergangsbereich
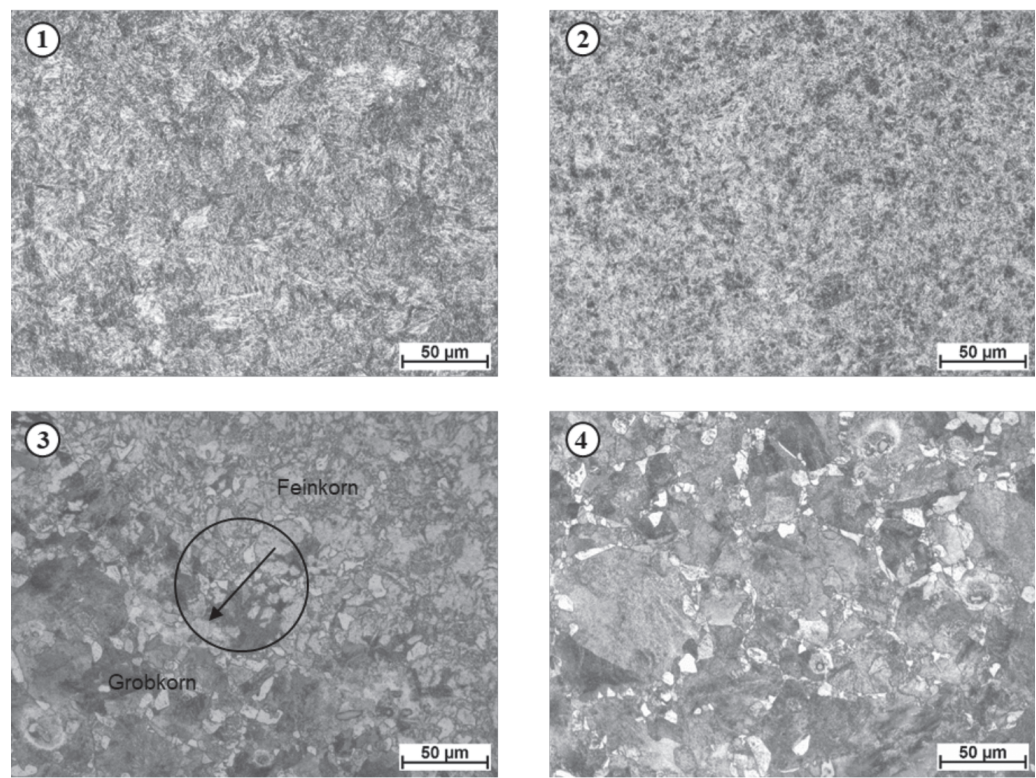
surface) (1). In this area of the fillet, a fine-grained martensitic microstructure is observed. Deeper in the material a sudden steep hardness drop of approx. 300 HV 0.5 appears (labeled (2)). In contrast to area (3) (in Figure 3), a coarsening of the prevailing microstructure cannot be deduced from area (2) in Figure 4. Within this area predominantly martensite and bainite are present. With increasing surface distance (3) the initial ferritic-perlitic as well as bainitic microstructure can be seen. Compared to area (4) in Figure 3 the initial microstructure is much finer. Moreover, hardness values reach the average hardness level of the initial condition.

In the following, residual stress profiles and integral width distributions as obtained by X-ray diffraction are discussed. In Figures 5 (residual stress) and Figure 6 (integral width) X-ray diffraction results for the $38 \mathrm{MnSiVS} 5$ (a, c, e) and the $42 \mathrm{CrMo} 4$ (b, d, f) in the initial condition as well as for the deep rolled and the induction hardened fillet areas are displayed.

For the initial condition in Figures $5 \mathrm{a}$ and $\mathrm{b}$ residual stress profiles are characterized by scatter and ill-defined courses along the five measuring angles, resulting from a superposition of air-cooling and machining. In this context, scatter displayed for the $38 \mathrm{Mn}$ SiVS5 (ranging from $120 \mathrm{MPa}$ to $45 \mathrm{MPa}$ ) is more pronounced as compared to scatter shown for the $42 \mathrm{CrMo} 4$ (ranging from $-90 \mathrm{MPa}$ to $7 \mathrm{MPa}$ ). Figures $5 \mathrm{c}$ and d clearly demonstrate that the deep rolling process has induced a new residual stress state, which is characterized by high compressive residual stress values. Scatter seen in the initial state disappeared. Respective absolute values differ depending on the measurement direction. Residual stress profiles for the $\mathrm{Q}+\mathrm{T}$ steel are slightly shifted towards a compressive stress state. In this context, the maximum compressive resid- che (ca. 0,5 mm von der Oberfläche) gemessen (1). In diesem Bereich der Hohlkehle wird ein feinkörniges martensitisches Gefüge nachgewiesen. Tiefer im Material zeigt sich ein plötzlicher steiler Härteabfall von ca. 300 HV 0,5 (beschriftet mit (2)). Im Gegensatz zum Bereich (3) (Bild 3) kann im Bereich (2) in Bild 4 nicht auf eine Vergröberung des vorherrschenden Gefüges geschlossen werden. In diesem Bereich sind überwiegend Martensit und Bainit vorhanden. Mit zunehmendem Flächenabstand (3) ist das anfänglich ferritisch-perlitische sowie bainitische Gefüge zu erkennen. Im Vergleich zum Bereich (4) in Bild 3 ist das Ausgangsgefüge deutlich feiner. Außerdem erreichen die Härtewerte das mittlere Härteniveau des Ausgangszustandes.

Im Folgenden werden Eigenspannungsprofile und integrale Breitenverteilungen, wie sie durch Röntgenbeugung erhalten wurden, diskutiert. In Bild 5 (Eigenspannungen) und Bild 6 (integrale Breite) sind Röntgenbeugungsergebnisse für 38MnSiVS5 (a, c, e) und 42CrMo4 (b, d, f) im Ausgangszustand sowie für die tiefgewalzten und induktionsgehärteten Verrundungsbereiche dargestellt.

Für den Ausgangszustand in Bild 5a und b sind die Eigenspannungsprofile durch Streuungen und undefinierte Verläufe entlang der fünf Messwinkel gekennzeichnet, die aus einer Überlagerung von Luftabkühlung und Bearbeitung resultieren. Dabei sind die Streuungen bei 38MnSiVS5 (im Bereich von $120 \mathrm{MPa}$ bis $45 \mathrm{MPa}$ ) stärker ausgeprägt als bei 42CrMo4 (im Bereich von -90 MPa bis $7 \mathrm{MPa}$ ). Bild $5 \mathrm{c}$ und $5 \mathrm{~d}$ zeigen deutlich, dass der Festwalzprozess einen neuen Eigenspannungszustand induziert hat, der durch hohe Druckeigenspannungswerte gekennzeichnet ist. Die im Ausgangszustand beobachteten Streuungen sind verschwunden. Die jeweiligen Absolutwerte unterscheiden sich je nach Messrichtung. Die Eigenspannungsprofile für den Q+T-Stahl sind leicht in Richtung eines Druckspannungszustandes verschoben. In diesem $\mathrm{Zu}$ -
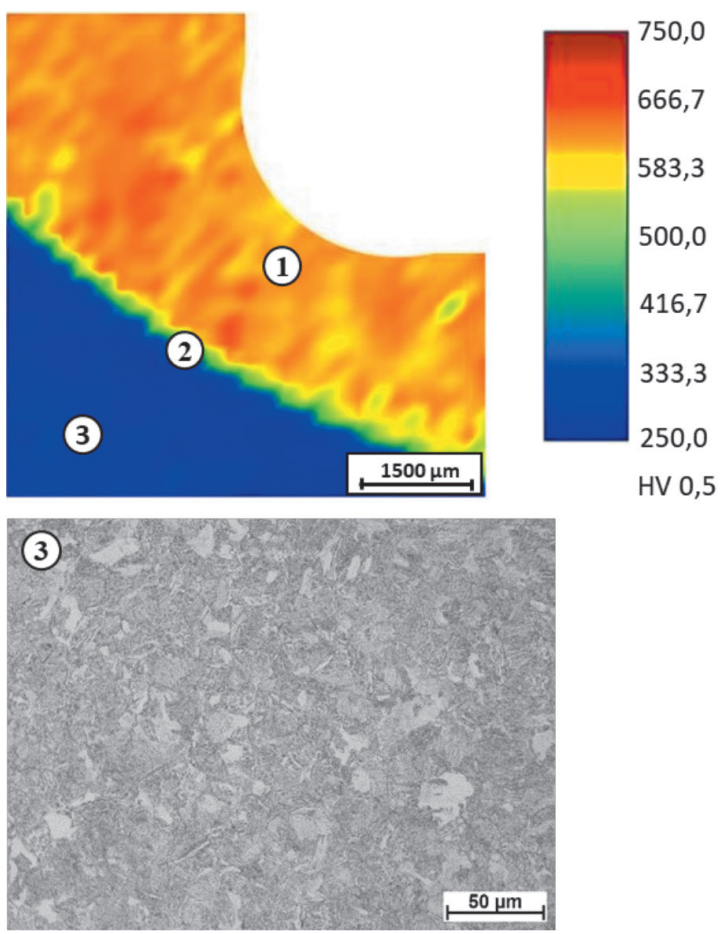

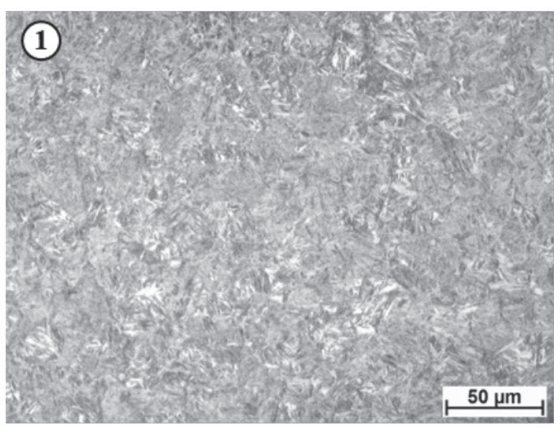

HV 0,5

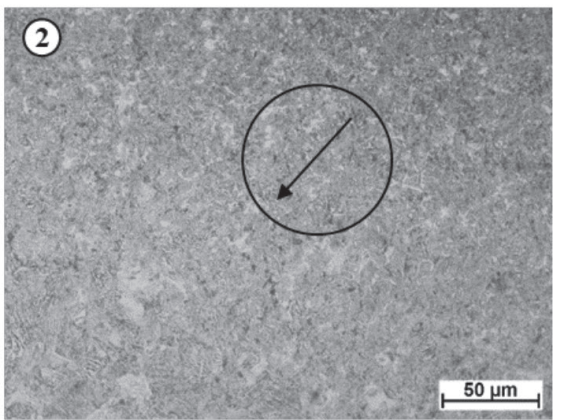

Fig. 4. Full-field hardness distribution of the inductionhardened crankshaft fillet of the $42 \mathrm{CrMo} 4$ as well as microstructural sections: (1) in the upper fillet area, (2) in the transition area, (3) below the transition area (labeling in German)

Bild 4. Härtemapping und Messwertskala der induktionsgehärteten Hohlkehle des $42 \mathrm{CrMo} 4$ sowie Gefügeanschliffe: (1) im Scheitelbereich der Hohlkehle, (2) im Übergangsbereich, (3) nach dem Übergangsbereich 
Fig. 5. Residual stress distribution of the initial condition ((211) plane of ferrite): a) 38MnSiVS5, b) $42 \mathrm{CrMo4}$; deep rolled fillet area: c) $38 \mathrm{MnSiVS5}$, d) 42CrMo4; induction hardened fillet area: e) $38 \mathrm{MnSiVS5}$, f) $42 \mathrm{CrMo} 4$

Bild 5. Eigenspannungsverteilung des Ausgangszustandes ((211)-Ebene des Ferrits): a) $38 \mathrm{MnSiVS5}$, b) $42 \mathrm{CrMo} 4$; des festgewalzten Hohlkehlenbereichs: c) 38MnSiVS5, d) $42 \mathrm{CrMo} 4$; des induktionsgehärteten Hohlkehlenbereichs: e) $38 \mathrm{MnSiVS5}$, f) $42 \mathrm{CrMo} 4$ a) 100

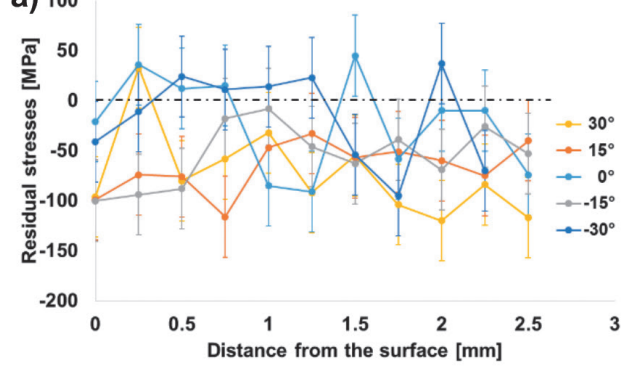

c)

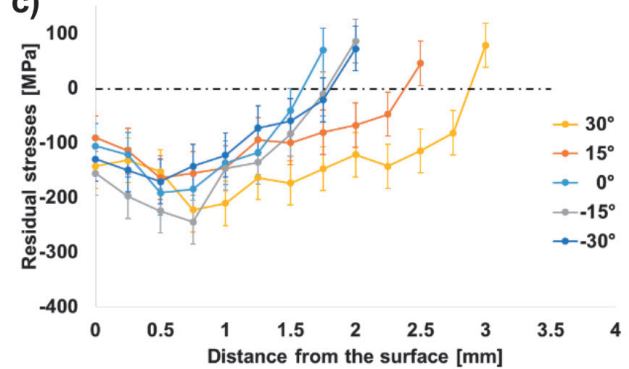

e)

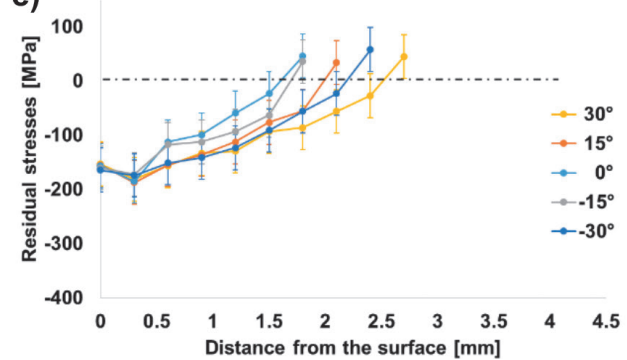

b) 100

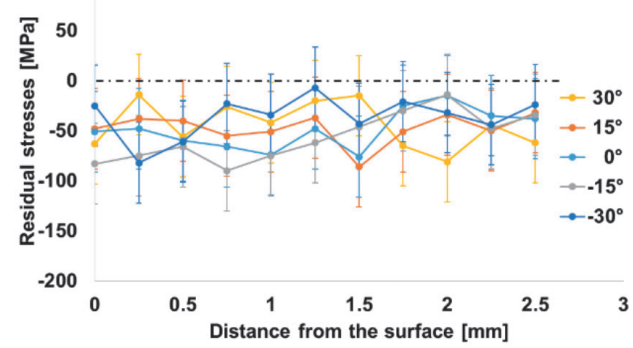

d)

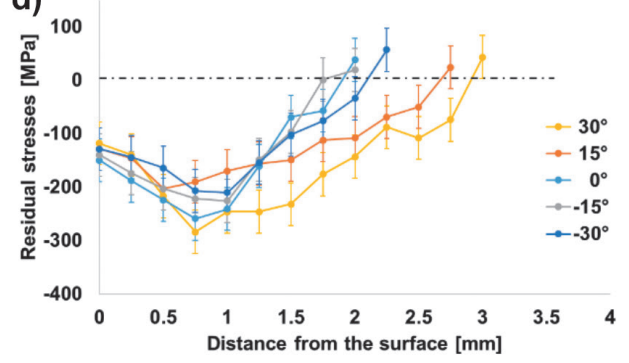

f)

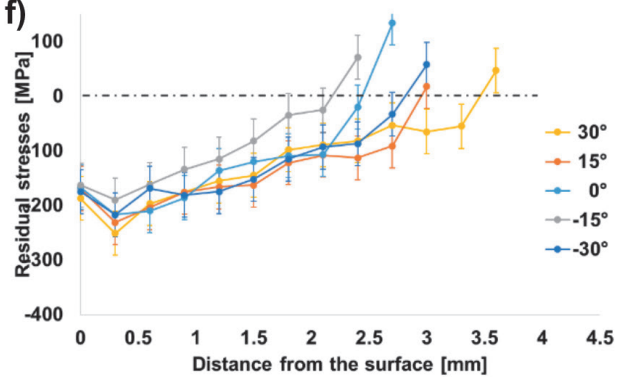

ual stress value of the $42 \mathrm{CrMo} 4(-284 \mathrm{MPa})$ slightly exceeds the maximum value of the $38 \mathrm{MnSiVS} 5(-245 \mathrm{MPa})$, occuring in depths of $0.5 \mathrm{~mm}$ to $1 \mathrm{~mm}$ from the surface. However, results shown for the $38 \mathrm{MnSiVS} 5$ as well as for the $42 \mathrm{CrMo} 4$ reveal very similar courses. The transition zones for both steels considering all measuring angles range from $1.65 \mathrm{~mm}$ to $2.85 \mathrm{~mm}$.

In Figures $5 \mathrm{e}$ and $\mathrm{f}$ residual stress profiles after induction hardening are displayed. Compared to the deep-rolled condition, differences between measurement directions in this condition are much smaller. In particular, the surface layer of the medium carbon microalloyed steel reveals an almost homogeneous hardening layer down to a depth of $0.25 \mathrm{~mm}$. Again, residual stress profiles for the Q+T steel are slightly shifted towards a higher compressive residual stress state. In contrast to the deep-rolling results, maximum compressive residual stress values are already reached in a depth of $0.25 \mathrm{~mm}$. In terms of absolute values, the $42 \mathrm{CrMo} 4(-251 \mathrm{MPa})$ exceeds the 38MnSiVS5 $(-187 \mathrm{MPa})$. The transition zones displayed for the microalloyed steel range from $1.6 \mathrm{~mm}$ to $2.5 \mathrm{~mm}$. In comparison, the transition range for the $\mathrm{Q}+\mathrm{T}$ steel is characterized by higher width and simultaneously shifted towards a deeper component region (from $2.2 \mathrm{~mm}$ to $3.45 \mathrm{~mm}$ ). sammenhang übersteigt der maximale Druckeigenspannungswert des 42CrMo4 (-284 MPa) leicht den maximalen Wert des 38MnSiVS5 (-245 MPa), der in Tiefen von $0,5 \mathrm{~mm}-1 \mathrm{~mm}$ von der Oberfläche auftritt. Die Ergebnisse für den $38 \mathrm{MnSiVS5}$ wie auch für den $42 \mathrm{CrMo} 4$ zeigen jedoch sehr ähnliche Verläufe. Die Übergangszonen für beide Stähle unter Berücksichtigung aller Messwinkel lagen zwischen 1,65 $\mathrm{mm}$ und 2,85 $\mathrm{mm}$.

In Bild $5 e$ und $5 f$ sind Eigenspannungsprofile nach dem Induktionshärten dargestellt. Im Vergleich zum tiefgewalzten $\mathrm{Zu}$ stand sind die Unterschiede zwischen den Messrichtungen in diesem Zustand deutlich geringer. Insbesondere die Randschicht des mikrolegierten Stahls mit mittlerem Kohlenstoffgehalt zeigt bis zu einer Tiefe von 0,25 mm eine nahezu homogene Härteschicht. Auch hier sind die Eigenspannungsprofile für den Q+T-Stahl leicht in Richtung eines Druckeigenspannungszustandes verschoben. Im Gegensatz zu den Ergebnissen des Festwalzens werden maximale Druckeigenspannungswerte bereits in einer Tiefe von $0,25 \mathrm{~mm}$ erreicht. Bei den absoluten Werten übertrifft der 42CrMo4 (-251 MPa) den 38MnSiVS5 (-187 MPa). Die angezeigten Übergangszonen für den mikrolegierten Stahl reichten von 1,6 mm-2,5 mm. Im Vergleich dazu ist der Übergangsbereich für den Q+T-Stahl durch eine höhere Breite gekennzeichnet und gleichzeitig in einen tieferen Bauteilbereich verschoben (von 2,2 $\mathrm{mm}-3,45 \mathrm{~mm})$. 
a)

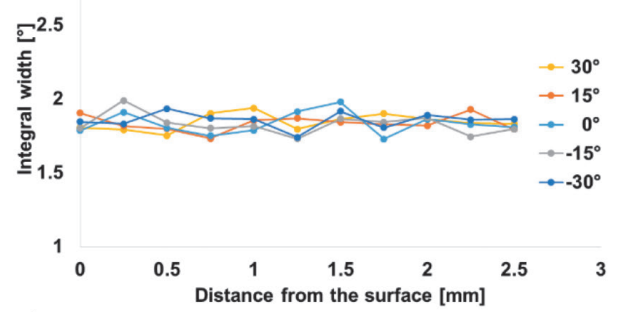

c) 3

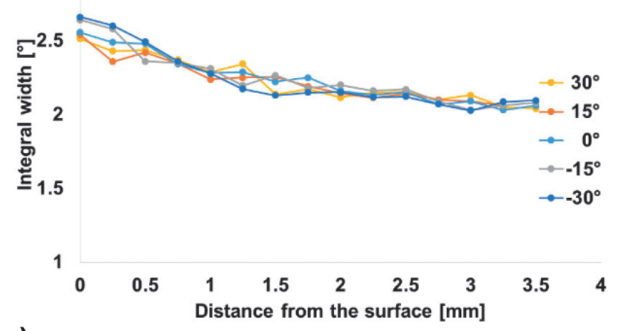

e) 6.5

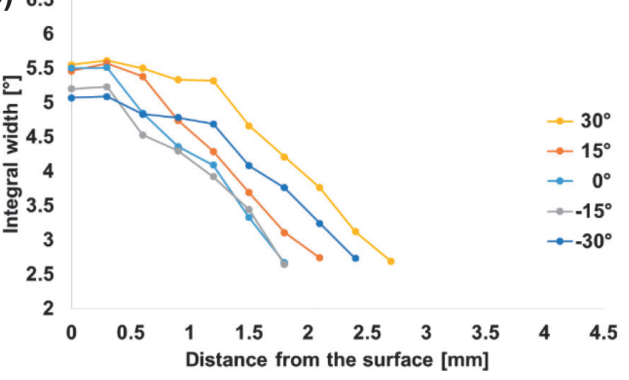

b) 3
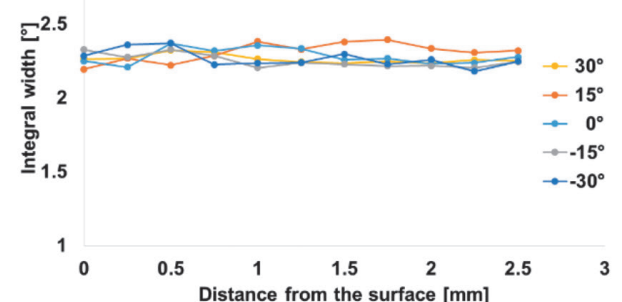

d) 3
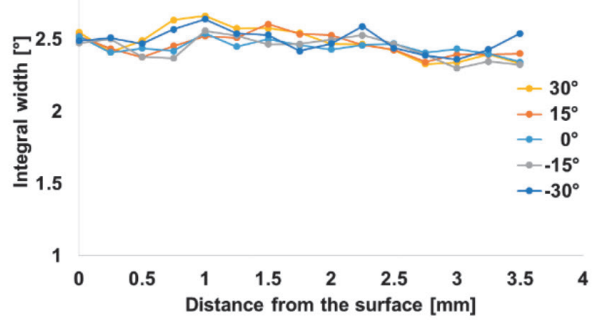

f) 6.5

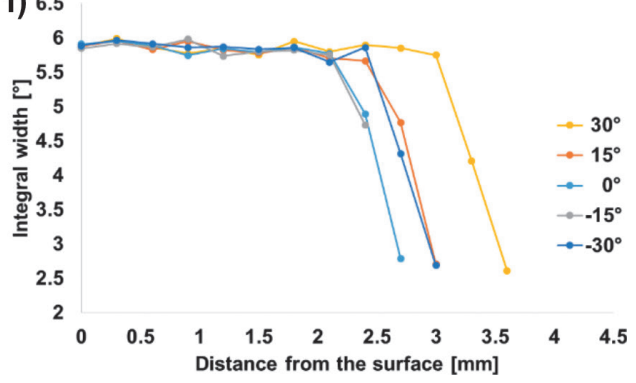

Fig. 6. Integral width distribution of the initial condition ((211) plane of ferrite): a) 38MnSiVS5,

b) $42 \mathrm{CrMo4}$; deep rolled fillet area: c) $38 \mathrm{MnSiVS5}$, d) $42 \mathrm{CrMo} 4$; induction hardened fillet area: e) $38 \mathrm{MnSiVS5}$, f) $42 \mathrm{CrMo} 4$

Bild 6. Integralbreitenverteilung des Ausgangszustandes ((211) Ebene des Ferrits): a) $38 \mathrm{MnSiVS5}$, b) $42 \mathrm{CrMo4}$; des festgewalzten Hohlkehlenbereiches: c) $38 \mathrm{MnSiVS5}$, d) $42 \mathrm{CrMo4}$; des induktionsgehärteten Hohlkehlenbereiches: e) 38MnSiVS5, f) $42 \mathrm{CrMo} 4$
According to Figures $6 \mathrm{a}$ and $\mathrm{b}$ integral width results (initial condition) of the microalloyed and the Q+T steel are displayed. Values seen remain on a relatively constant level to a depth of $2.5 \mathrm{~mm}$. In this context, the $38 \mathrm{MnSiVS} 5$ exhibits a lower average integral width value of $1.84^{\circ}$ as compared to the mean average integral width of $2.26^{\circ}$ for the $42 \mathrm{CrMo} 4$.

The results shown in Figures $6 \mathrm{c}$ and $\mathrm{d}$ in the deep rolled condition reveal an almost uniform integral width distribution in the fillet region. In contrast to the $42 \mathrm{CrMo} 4$, the $38 \mathrm{MnSiVS} 5$ shows a more pronounced increase of integral width values in direct vicinity of the surface region, afterwards declining fast until initial properties are met. In fact, the mean average integral width level increased to $2.15^{\circ}$ (38MnSiVS5) and $2.51^{\circ}(42 \mathrm{CrMo} 4)$, respectively.

Integral width distributions after the induction hardening process are shown in Figures $6 \mathrm{e}$ and $\mathrm{f}$. It should be noted that integral width profiles of the fillet region for the 38MnSiVS5 differ significantly from the results of the $42 \mathrm{CrMo} 4$. Profiles being representative for the microalloyed steel are characterized by pronounced differences for the different measuring directions. At a given distance from the surface, integral width values abruptly decline until initial properties are reached. In contrast, profiles displayed for the Q+T steel reveal a homogeneous integral width state hardly declining up to a depth of $2.25 \mathrm{~mm}$. Afterwards, a sudden drop can be seen. Maximum values are found at a depth of $0.25 \mathrm{~mm}$.
In Bild 6a und 6b sind die Ergebnisse der integralen Breite (Ausgangszustand) des mikrolegierten und des Q+T-Stahls dargestellt. Die gesehenen Werte bleiben bis zu einer Tiefe von 2,5 mm auf einem relativ konstanten Niveau. Dabei zeigt der 38MnSiVS5 einen geringeren mittleren Integralbreitenwert von $1,84^{\circ} \mathrm{im}$ Vergleich zum mittleren Integralbreitenmittelwert von $2,26^{\circ}$ für den $42 \mathrm{CrMo} 4$.

Die in Bild $6 \mathrm{c}$ und $6 \mathrm{~d}$ dargestellten Ergebnisse im tiefgewalzten Zustand zeigen eine nahezu gleichmäßige Integralbreitenverteilung im Kehlbereich. Im Gegensatz zum 42CrMo4 zeigt das 38MnSiVS5 einen ausgeprägteren Anstieg der Integralbreitenwerte in unmittelbarer Nähe des Oberflächenbereichs, der danach schnell abnimmt, bis die ursprünglichen Eigenschaften erreicht sind. Tatsächlich stieg das mittlere Niveau der Integralbreite auf $2,15^{\circ}$ (38MnSiVS5) bzw. 2,51 ${ }^{\circ}$ (42CrMo4) an.

Die Integralbreitenverteilungen nach dem Induktionshärtungsprozess sind in Bild 6e und $6 \mathrm{f}$ dargestellt. Es ist zu beachten, dass sich die Integralbreitenprofile des Verrundungsbereichs für $38 \mathrm{MnSiVS} 5$ deutlich von den Ergebnissen für 42CrMo4 unterscheiden. Die Profile, die für den mikrolegierten Stahl repräsentativ sind, zeichnen sich durch ausgeprägte Unterschiede für die verschiedenen Messrichtungen aus. Bei einem gegebenen Abstand von der Oberfläche nehmen die Werte der integralen Breite abrupt $\mathrm{ab}$, bis die ursprünglichen Eigenschaften erreicht sind. Im Gegensatz dazu zeigen die für den Q+T-Stahl dargestellten Profile einen homogenen Integralbreitenzustand, der bis $\mathrm{zu}$ einer Tiefe von 

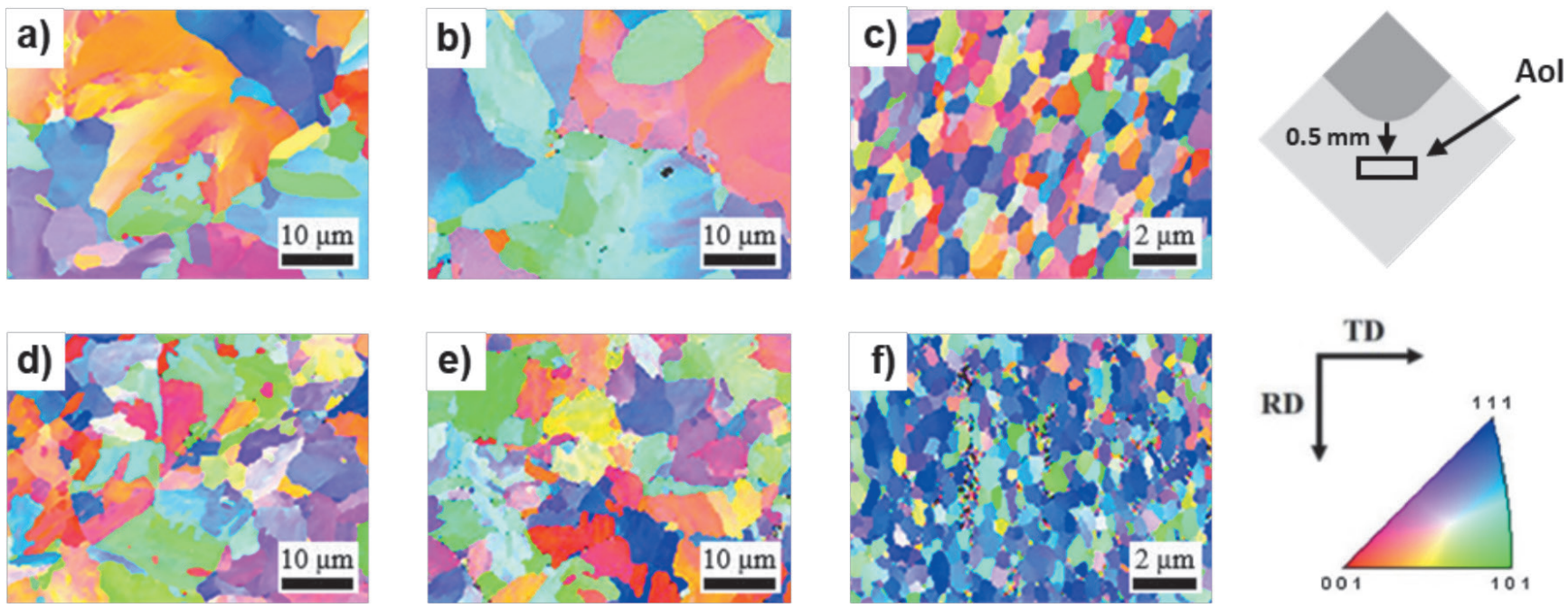

Fig. 7. OIM maps for the initial condition: a) 38MnSiVS5, d) 42CrMo4; deep rolled fillet area: b) 38MnSiVS5, e) 42CrMo4; induction hardened fillet area: c) $38 \mathrm{MnSiVS5}$, f $42 \mathrm{CrMo} 4$. Measuring position (Aol) and color coding of grain orientation (in accordance to the standard triangle) are shown to the right. Grain orientations are plotted with respect to the surface normal of the cross section. Please note the different scale bar for the induction hardened fillet area

Bild 7. OIM-Maps des Ausgangszustandes: a) 38MnSiVS5, d) 42CrMo4; des festgewalzten Hohlkehlenbereiches: b) 38MnSiVS5, e) 42CrMo4; des induktionsgehärteten Hohlkehlenbereiches: c) 38MnSiVS5, f) 42CrMo4. Messposition (Aol) und Farbkodierung der Kornorientierung (gemäß Normdreieck) sind rechts dargestellt. Die Kornorientierungen sind in Bezug auf die Oberflächennormale der Hohlkehle aufgetragen. Unterschiedliche Maßstabsbalken für den induktionsgehärteten Hohlkehlenbereich sind zu beachten

\subsection{EBSD and ECCI Measurements}

Results obtained from EBSD and ECCI for both steel grades (38MnSiVS5 and 42CrMo4) are displayed in Figures 7-9. Data plotted as orientation image maps (OIM) can be seen in Figure 7, whereas the findings related to analysis of the kernel average misorientation (KAM) are depicted in Figure 8. Results obtained by ECCI analysis are shown in Figure 9.

Qualitatively the quenched and tempered $42 \mathrm{CrMo} 4$ steel is characterized by smaller grains as compared to the medium carbon $38 \mathrm{MnSiVS} 5$ microalloyed steel (as deduced from direct comparison of Figures $7 \mathrm{a}$ and d. A preferred grain orientation cannot be stated for any of the two initial conditions. In Figures $7 \mathrm{~b}$ and $\mathrm{e}$ OIM in the deep rolled condition for both steel grades are depicted. The differences in the average grain size between the microalloyed steel and the Q+T steel are maintained. Again, OIM do not indicate a preferred grain orientation. OIM of the induction hardened fillet area are displayed in Figures $7 \mathrm{c}$ and $\mathrm{f}$. Compared to the previous surface layer conditions a significant decrease of the average grain size can be observed.

In order to examine the surface layer in more detail (focusing on the evolution of local misorientation within single grains) KAM were evaluated. The AoI of the initial condition shown in Figures $8 \mathrm{a}$ and $\mathrm{d}$ reveal low misorientation values across the scanning field for both
2,25 mm kaum abnimmt. Danach ist ein plötzlicher Abfall zu erkennen. Maximale Werte werden in einer Tiefe von $0,25 \mathrm{~mm}$ gefunden.

\subsection{EBSD- und ECCI-Messungen}

Die Ergebnisse von EBSD und ECCI für beide Stahlsorten (38MnSiVS5 und 42CrMo4) sind in Bild 7 bis 9 dargestellt. Die Daten, die als Orientierungsbildkarten (OIM) aufgezeichnet wurden, sind in Bild $7 \mathrm{zu}$ sehen, während die Ergebnisse, die sich auf die Analyse der Kernel Average Misorientation (KAM) beziehen, in Bild 8 dargestellt sind. Die Ergebnisse der ECCI-Analyse sind in Bild 9 dargestellt.

Qualitativ ist der vergütete $42 \mathrm{CrMo} 4-\mathrm{Stahl}$ durch kleinere Körner im Vergleich zum mikrolegierten 38MnSiVS5-Stahl mit mittlerem Kohlenstoffgehalt gekennzeichnet (wie aus dem direkten Vergleich von Bild 7a und 7d abgeleitet). Eine bevorzugte Kornorientierung kann für keinen der beiden Ausgangszustände angegeben werden. In Bild 7b und 7e sind die OIM-Karten im tiefgewalzten Zustand für beide Stahlsorten dargestellt. Die Unterschiede in der durchschnittlichen Korngröße zwischen dem mikrolegierten Stahl und dem Q+T-Stahl bleiben erhalten. Auch hier weisen die OIM-Karten nicht auf eine bevorzugte Kornorientierung hin. OIM-Karten des induktionsgehärteten Kehlbereichs sind in Bild $7 \mathrm{c}$ und $7 \mathrm{f}$ dargestellt. Im Vergleich zu den vorherigen Randschichtbedingungen ist eine deutliche Abnahme der durchschnittlichen Korngröße zu beobachten.

Um die Randschicht genauer zu untersuchen (mit Fokus auf die Entwicklung der lokalen Fehlorientierung innerhalb einzelner Körner), wurden KAM-Karten ausgewertet. Die in Bild 8a und 8d dargestellten AoIs des Ausgangszustandes zeigen für beide Stahl- 

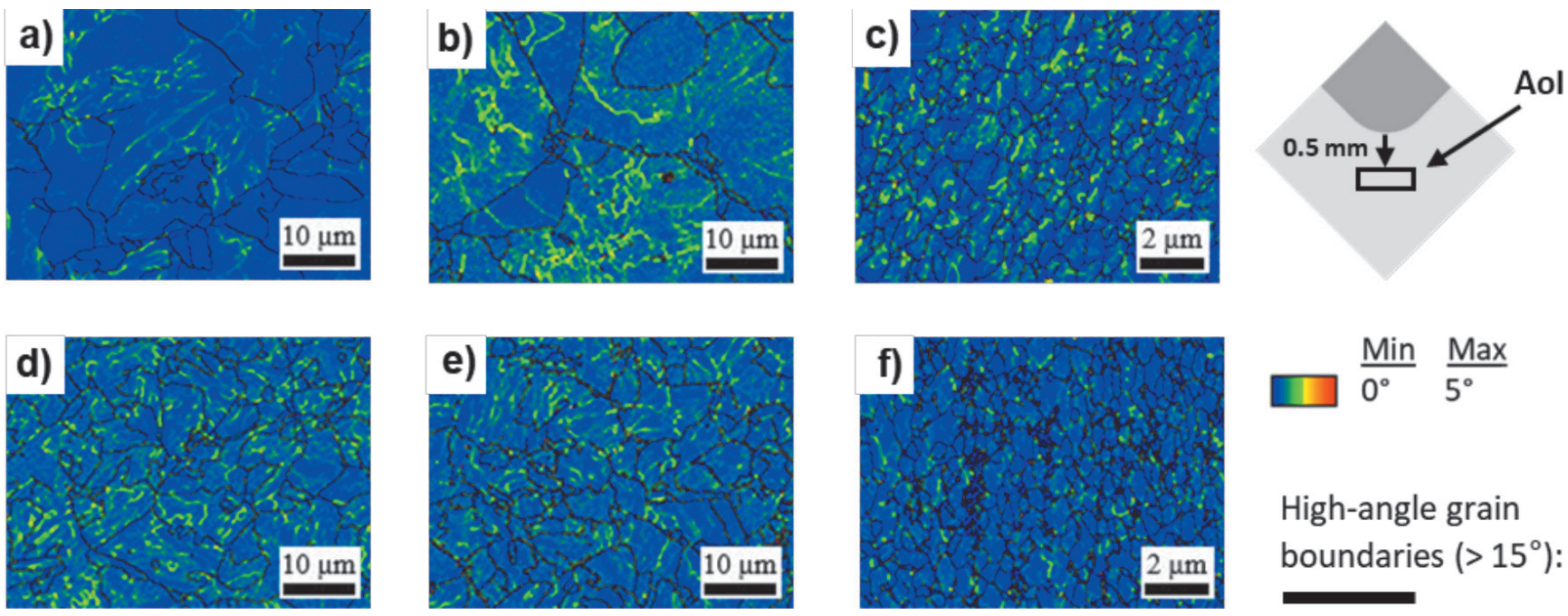

Fig. 8. KAM maps for the initial condition: a) 38MnSiVS5, d) 42CrMo4; deep rolled fillet area: b) 38MnSiVS5, e) 42CrMo4; induction hardened fillet area: c) $38 \mathrm{MnSiVS5}$, f) $42 \mathrm{CrMo4}$. Measuring position (Aol); color coding of local misorientation is in accordance to the color bar on the right. High-angle-boundaries $\left(>15^{\circ}\right)$ are superimposed by black lines. Please note the different scale bar for the induction hardened fillet area

Bild 8. KAM-Maps des Ausgangszustandes: a) 38MnSiVS5, d) 42CrMo4; des festgewalzten Hohlkehlenbereiches: b) 38MnSiVS5, e) 42CrMo4; des induktionsgehärteten Hohlkehlenbereiches: c) 38MnSiVS5, f) 42CrMo4. Messposition (Aol) sowie Farbkodierung der lokalen Missorientierung (Farbkodierung entspricht dem Farbbalken rechts). Großwinkelkorngrenzen $\left(>15^{\circ}\right)$ sind durch schwarze Linien gekennzeichnet. Unterschiedliche Maßstabsbalken für den induktionsgehärteten Hohlkehlenbereich sind zu beachten

steel grades. Generally, low overall misorientation with an average $\mathrm{KAM}$ value of $0.56^{\circ}(38 \mathrm{MnSiVS} 5)$ and $0.63^{\circ}(42 \mathrm{CrMo} 4)$ can be deduced. According to Figures $8 \mathrm{~b}$ and e, local misorientation increased to $0.79^{\circ}(38 \mathrm{MnSiVS} 5)$ and $0.75^{\circ}$ (42CrMo4), respectively, upon deep rolling. Furthermore, color gradients are seen primarily at grain boundaries. Figures $8 \mathrm{c}$ and $\mathrm{f}$ illustrate the AoI of the induction hardened area. In contrast to the deep rolled fillet area, the average KAM values are lower and only increased to $0.7^{\circ}$ for the microalloyed steel and $0.62^{\circ}$ for the $\mathrm{Q}+\mathrm{T}$ steel.

Figure 9 shows the results obtained by ECCI for the medium carbon microalloyed steel and the $\mathrm{Q}+\mathrm{T}$ steel with regard to the three material conditions. Due to differences in size of prevailing microstructural features, ECCI analysis was conducted at different magnifications. Figures $9 \mathrm{a}$ and $\mathrm{b}$ reveal representative microstructural features for the initial state. Independent of the material considered, occasional crystal defects mainly accumulate in direct vicinity of grain boundaries, triple-points and randomly also within grains. As highlighted in Figures $9 \mathrm{c}$ and d, a significant increase of density of microstructural defects as compared to the initial condition is observed after deep rolling. A clear differentiation between individual lattice defects is hardly possible due to the strong accumulation and superposition of different crystal defects in the representative areas shown. This is particularly evident in the formation of dislocation substructures. Respective areas are marked by white arrows in Figures $9 \mathrm{c}$ and $\mathrm{d}$. The impact of induction hardening on microstructural evolution is detailed in Figures $9 \mathrm{e}$ and $\mathrm{f}$. After induction hardening, an even more pronounced increase in density of defects is observed than after deep rolling. However, the defect arrangement induced by induction hardening clearly differs sorten geringe Fehlorientierungswerte über das gesamte Scanfeld. Generell lässt sich eine geringe Gesamtfehlausrichtung mit einem mittleren KAM-Wert von $0,56^{\circ}$ (38MnSiVS5) und $0,63^{\circ}$ (42CrMo4) ableiten. Nach Bild $8 \mathrm{~b}$ und $8 \mathrm{e}$ nimmt die lokale Fehlorientierung beim Festwalzen auf $0,79^{\circ}$ (38MnSiVS5) bzw. 0,75 ${ }^{\circ}$ (42CrMo4) zu. Außerdem sind Farbgradienten vor allem an den Korngrenzen zu sehen. Bild $8 \mathrm{c}$ und $8 \mathrm{f}$ zeigen den AoI des induktionsgehärteten Bereichs. Im Gegensatz zum festgewalzten Kehlbereich sind die durchschnittlichen KAM-Werte niedriger und stiegen nur auf $0,7^{\circ}$ für den mikrolegierten Stahl und 0,62 für den Q+T-Stahl.

Bild 9 zeigt die mit ECCI erzielten Ergebnisse für den mikrolegierten Stahl mit mittlerem Kohlenstoffgehalt und den Q+T-Stahl in Bezug auf die drei Materialbedingungen. Aufgrund der unterschiedlichen Größe der vorherrschenden Gefügemerkmale wurde die ECCI-Analyse mit unterschiedlichen Vergrößerungen durchgeführt. Bild $9 \mathrm{a}$ und $9 \mathrm{~b}$ zeigen repräsentative Gefügemerkmale für den Ausgangszustand. Unabhängig vom betrachteten Material häufen sich gelegentliche Kristalldefekte hauptsächlich in unmittelbarer Nähe von Korngrenzen, Tripelpunkten und zufällig auch innerhalb von Körnern. Wie in Bild $9 \mathrm{c}$ und $9 \mathrm{~d}$ hervorgehoben, ist nach dem Festwalzen eine deutliche Zunahme der Gefügefehlerdichte im Vergleich zum Ausgangszustand zu beobachten. Eine klare Unterscheidung zwischen einzelnen Gitterfehlern ist aufgrund der starken Anhäufung und Überlagerung verschiedener Kristalldefekte in den dargestellten repräsentativen Bereichen kaum möglich. Besonders deutlich wird dies bei der Ausbildung von Versetzungssubstrukturen. Entsprechende Bereiche sind in Bild 9c und 9d durch weiße Pfeile gekennzeichnet. Der Einfluss der Induktionshärtung auf die Gefügeentwicklung ist in Bild 9e und 9f detailliert dargestellt. Nach dem Induktionshärten wird ein drama- 
Fig. 9. ECCl micrographs revealing microstructural features for the initial condition a) $38 \mathrm{MnSiVS5}$

b) $42 \mathrm{CrMo4}$; deep rolled fillet area c) $38 \mathrm{MnSiVS5}$, d) $42 \mathrm{CrMo} 4$ induction hardened fillet area e) $38 \mathrm{MnSiVS5}$, f) $42 \mathrm{CrMo} 4$

Bild 9. ECCl-Auswertung bezgl. der Gefügemerkmale für den Ausgangszustand a) $38 \mathrm{MnSiVS5}$, b) $42 \mathrm{CrMo4}$; den festgewalzten Hohlkehlenbereich c) $38 \mathrm{MnSiVS5}$, d) $42 \mathrm{CrMo4}$; den induktionsgehärteten Hohlkehlenbereich e) $38 \mathrm{MnSiVS5}$, f $42 \mathrm{CrMo} 4$ a)
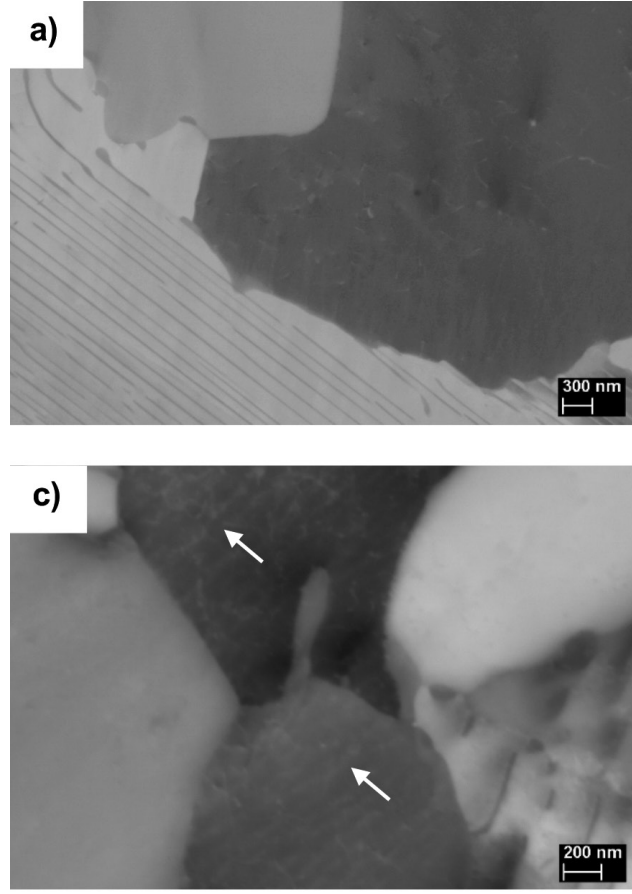

e)

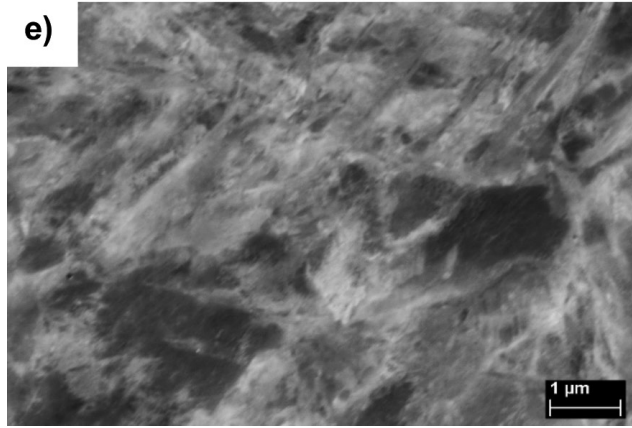

b)

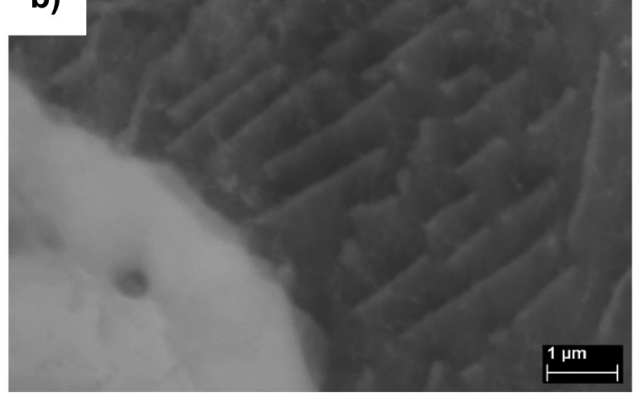

d)

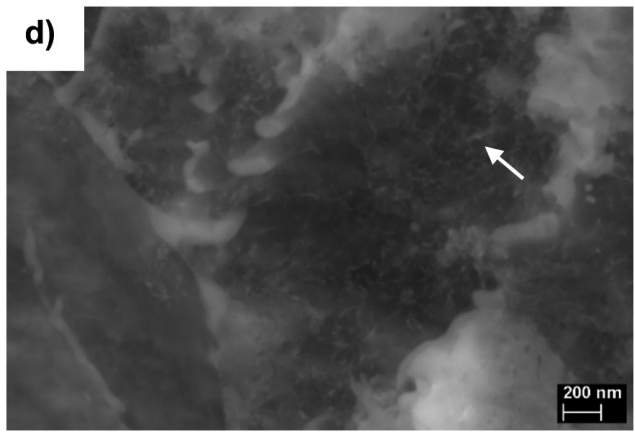

f)

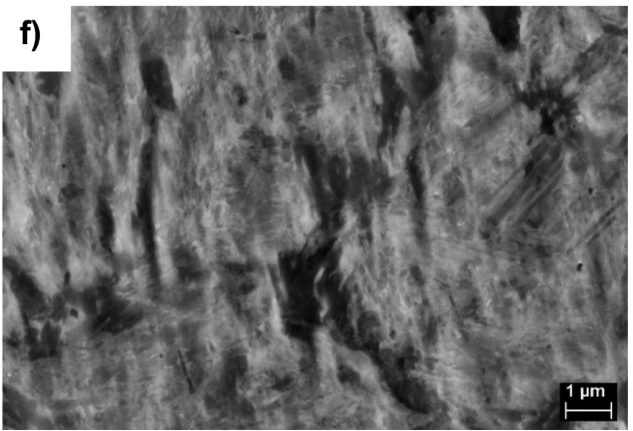

from the deep-rolled state, where a blurred defect structure evolved. Again, a distinction between different elementary features is hardly feasible. In general, representative microstructural characteristics imposed by different surface layer treatments can be clearly identified, but no significant differences can be resolved between the $38 \mathrm{MnSiVS} 5$ and the $42 \mathrm{CrMo} 4$ based on ECCI.

\section{Discussion}

4.1 General remarks on determination and evaluation of surface properties upon induction hardening and deep rolling

As indicated in Figures $5 \mathrm{c}-\mathrm{f}$ deep rolling and induction hardening lead to similar courses of the residual stress profiles. However, mi- tischerer Anstieg der Defektdichte beobachtet als nach dem Festwalzen. Die Defektanordnung nach dem Induktionshärten unterscheidet sich jedoch deutlich vom tiefgewalzten Zustand, wo sich eine unscharfe Defektstruktur entwickelt hat. Auch hier ist eine Unterscheidung zwischen verschiedenen elementaren Merkmalen kaum möglich. Generell lassen sich repräsentative Gefügemerkmale, die durch unterschiedliche Randschichtbehandlungen hervorgerufen werden, deutlich erkennen, jedoch können keine signifikanten Unterschiede zwischen dem 38MnSiVS5 und dem 42CrMo4 auf Basis von ECCI aufgelöst werden.

\section{Diskussion}

\subsection{Allgemeine Bemerkungen zur Ermittlung und Bewertung der Oberflächeneigenschaften beim Induktionshärten und Festwalzen}

Wie in Bild 5c-f dargestellt, führen Festwalzen und Induktionshärten zu ähnlichen Verläufen der Eigenspannungsprofile. Es sind jedoch ge- 
nor differences with regard to the achieved penetration depth between the $38 \mathrm{MnSiVS} 5$ and the $42 \mathrm{CrMo} 4$ in the induction hardened condition can be seen. In comparison to residual stress results detailed in Figures $5 c-f$, hardness and integral width distributions displayed in Figures 2 and 6 reveal completely different courses upon application of established surface treatments, i. e. deep rolling and induction hardening independent from the steel considered. The reason for this discrepancy between the courses of the trendlines for integral widths and residual stresses obtained by $\mathrm{X}$-ray diffraction are related to the microstructural features responsible for those two values. Depending on the length scale, residual stresses have been subdivided in I., II. and III. kind [20]. Residual stresses of I. kind (macro stresses) have to be distinguished from micro stresses (II. and III. kind). Far-reaching (macro scale) residual stresses (I. kind) induced by deep rolled and induction hardening are of utmost importance for the final properties of the treated component. In fact, XRD measurements of residual stresses are very sensitive to residual stresses of I. and II. kind, such that locally different phase fractions may contribute to the final absolute values determined for a particular phase. On the contrary, residual stresses of III. kind are reflected by the integral width only. Thus, according to [20], an increase in the integral width pinpoints increasing micro stresses (residual stresses of the II. and III. kind). In general, all kinds of lattice defects such as inferfaces, dislocations, coherent and partially coherent precipitates etc. can lead to a broadening effect of the interference line profile [21]. Thus, an increase of hardness and integral width in the near-surface region can be interpreted as a clear indicator for local plastic deformation and strain hardening [6]. In this context, EBSD and ECCI can be effectively used in addition to XRD for fast qualitative evaluation of microstructural features imposed by any kind of surface treatment by analyzing color gradient distributions (KAM) as well as by evaluating the defect density on the basis of local brightness differences in the respective micrographs (ECCI). Due to the fact that microscopic stress fields strongly affect hardness determined by indentation as well, a well-defined correlation between the hardness values and the integral width results can be seen as detailed in Figures 2 and 6. However, highest hardness values are not an explicit indicator for an optimized macro residual stress state in these regions.

\subsection{Assessment of the role of initial material selection on the effectiveness of surface treatments and final component performance}

As detailed in chapter 3.1, hardness levels (Fig. 2) remain at a constant level across the fillet region for the medium carbon microalloyed steel as well as for the $\mathrm{Q}+\mathrm{T}$ steel in their respective initial conditions. Thereby, the initial hardness level of the $\mathrm{Q}+\mathrm{T}$ steel is characterized by higher absolute values as compared to the $38 \mathrm{MnSiVS} 5$. This fact is mainly attributed to differences in chemical composition, initial heat treatment states and average grain sizes (see Figures 3 and 4) [22, 23]. Hardness distributions obtained upon deep rolling (using parameters listed in chapter 2) only revealed a minor hardness increase in the vicinity of the sur- ringe Unterschiede hinsichtlich der erreichten Eindringtiefe zwischen dem 38MnSiVS5 und dem 42CrMo4 im induktionsgehärteten Zustand zu erkennen. Im Vergleich zu den detaillierten Eigenspannungsergebnissen in Bild $5 c-f$ zeigen die in Bild 2 und 6 dargestellten Härte- und Integralbreitenverteilungen bei Anwendung der etablierten Oberflächenbehandlungen, d. h. Festwalzen und Induktionshärten, unabhängig vom betrachteten Stahl völlig unterschiedliche Verläufe. Der Grund für diese Diskrepanz zwischen den Verläufen der mittels Röntgenbeugung ermittelten Trendlinien für Integralbreiten und Eigenspannungen liegt in den mikrostrukturellen Merkmalen, die für diese beiden Werte verantwortlich sind. Je nach Längenskala werden Eigenspannungen in I., II. und III. Art unterteilt [20]. Eigenspannungen der I. Art (Makrospannungen) sind von Mikrospannungen (II. und III. Art) zu unterscheiden. Weitreichende (Makro-) Eigenspannungen (I. Art), die durch das Festwalzen und Induktionshärten induziert werden, sind von größter Bedeutung für die endgültigen Eigenschaften des behandelten Bauteils. Tatsächlich sind XRD-Messungen von Eigenspannungen sehr empfindlich im Vergleich zu Eigenspannungen I. und II. Art, sodass lokal unterschiedliche Phasenanteile zu den für eine bestimmte Phase ermittelten End-Absolutwerten beitragen können. Im Gegensatz dazu werden Eigenspannungen III. Art nur durch die integrale Breite wiedergegeben. So zeigt nach [20] eine Zunahme der Integralbreite steigende Mikrospannungen (Eigenspannungen der II. und III. Art) an. Generell können alle Arten von Gitterfehlern wie z. B. Zwischenflächen, Versetzungen, kohärente und teilkohärente Ausscheidungen etc. zu einer Verbreiterung des Störlinienprofils führen [21]. Somit kann hier eine Zunahme der Härte und der Integralbreite im oberflächennahen Bereich als eindeutiger Indikator für lokale plastische Verformung und Kaltverfestigung interpretiert werden [6]. In diesem Zusammenhang können EBSD und ECCI zusätzlich zu XRD effektiv zur schnellen qualitativen Bewertung von Gefügemerkmalen eingesetzt werden, die durch eine beliebige Oberflächenbehandlung hervorgerufen wurden, indem Farbgradientenverteilungen (KAM) analysiert sowie die Defektdichte anhand lokaler Helligkeitsunterschiede in den jeweiligen Schliffbildern (ECCI) bewertet werden. Da die mikroskopischen Spannungsfelder auch die durch Eindrücken ermittelte Härte stark beeinflussen, ist ein eindeutiger Zusammenhang zwischen den Härtewerten und den Integralbreitenergebnissen zu erkennen, wie in Bild 2 und 6 dargestellt. Höchste Härtewerte sind jedoch kein eindeutiger Indikator für einen ausgeprägten Makroeigenspannungszustand in diesen Bereichen.

\subsection{Bewertung der Rolle der anfänglichen Material- auswahl auf die Wirksamkeit von Oberflächen- behandlungen und die endgültige Bauteilleistung}

Wie in Kapitel 3.1 beschrieben, bleiben die Härtewerte (Bild 2) sowohl für den mikrolegierten Stahl mit mittlerem Kohlenstoffgehalt als auch für den Q+T-Stahl in ihren jeweiligen Ausgangszuständen über den gesamten Verrundungsbereich auf einem konstanten Niveau. Dabei ist das Anfangshärteniveau des Q+TStahls durch höhere Absolutwerte im Vergleich zum 38MnSiVS5 gekennzeichnet. Diese Tatsache wird hauptsächlich auf Unterschiede in der chemischen Zusammensetzung, unterschiedliche anfängliche Wärmebehandlungszustände und sich unterscheidende durchschnittlichen Korngrößen zurückgeführt (siehe Bild 3 
face layer, which is in good agreement with investigations carried out by Cevik et al. [24]. In fact, the difference to the initial condition is marginal only. Still, the slight hardness increase in these areas can be predominantly attributed to the strain hardening effect imposed by localized plastic deformation during the deep-rolling process [25]. As can be seen from the ECCI results shown in Figure 9, dislocation substructures have already formed, revealing the presence of a kind of severly deformed, recovered saturation stage directly induced by deep rolling. This can be attributed to a relatively high number of rolling passes as well as an optimized ramp down rolling procedure applied at the end. Such structures are seen in both steels considered (Fig. $9 \mathrm{c}$ and d) pointing at deformation induced recovery processes eventually leading to characteristic pattern in the KAM maps (Fig. 8) and relatively high KAM values, being $0.79^{\circ}(38 \mathrm{MnSiVS5})$ and $0.75^{\circ}(42 \mathrm{CrMo} 4)$, respectively. In line with these findings and conclusions derived, hardly any changes are seen in the EBSD OIM (Fig. 7). Initial grain sizes are not affected and texture intensities seem not to have changed either. Most importantly, the overall evolution seen as well as final properties found are very similar for both steels. Thus, minor differences in final properties seen (in direct comparison of both steels, Figs. 2-9) are thought to be a remnant of differences of the initial conditions, no further differences are induced by the deep rolling treatment itself. As a consequence, distribution of residual stresses is very similar for both deep rolled conditions as well. As a minor effect the following has to be considered: residual stress courses for both steel grades display a more pronounced in-depth effect alongside angles of $30^{\circ}$ and $15^{\circ}$ as compared to the remaining measuring directions. This observation is expected to stem from different relative speeds between the tool and the workpiece in the contact surface as a consequence of the crankshaft fillet radius $(3.5 \mathrm{~mm})$ and the deep rolling angle of $34.85^{\circ}$. These factors lead to a multiaxial residual stress state in the surface layer, which is primarily responsible for the shift of the transition zone towards deeper material regions. Most importantly, it can be noted that deep rolling is very effective in introducing residual stresses of I. kind, as can be derived from direct comparison of residual stress values and integral widths of respective deep rolled and induction hardened conditions. Though integral width values (and hardness, respectively) are significantly higher in both induction hardened steels, residual stresses are fairly similar in terms of absolute values and distributions.

Obviously, in direct comparison of both steels, i. e. $38 \mathrm{MnSiVS5}$ and $42 \mathrm{CrMo} 4$, upon induction hardening, significant differences can be seen in local property evolution. Reasons for these obvious differences are discussed in the remainder of this chapter. und 4) [22, 23]. Die beim Festwalzen erhaltenen Härteverteilungen (unter Verwendung der in Kapitel 2 aufgeführten Parameter) zeigten nur einen geringen Härteanstieg in der Nähe der Randschicht, was in guter Übereinstimmung mit Untersuchungen von Cevik et al. steht [24]. In der Tat ist der Unterschied zum Ausgangszustand nur marginal. Dennoch kann der leichte Härteanstieg in diesen Bereichen überwiegend auf den Verfestigungseffekt durch die lokale plastische Verformung während des Festwalzprozesses zurückgeführt werden [25]. Wie aus den in Bild 9 dargestellten ECCI-Ergebnissen hervorgeht, haben sich bereits Versetzungssubstrukturen gebildet, die das Vorhandensein einer Art stark verformter, wiederhergestellter Sättigungsstufe offenbaren, die direkt durch das Festwalzen induziert wurde. Dies kann auf eine relativ hohe Anzahl von Walzstichen sowie auf ein optimiertes Abwärtswalzverfahren am Ende zurückgeführt werden. Solche Strukturen sind in beiden betrachteten Stählen $\mathrm{zu}$ sehen (Bild $9 \mathrm{c}$ und 9d), was auf verformungsinduzierte Erholungsprozesse hinweist, die schließlich zu charakteristischen Mustern in den KAM-Karten (Bild 8) und relativ hohen KAM-Werten führen, die $0,79^{\circ}$ (38MnSiVS5) bzw. $0,75^{\circ}$ (42CrMo4) betragen. In Übereinstimmung mit diesen Erkenntnissen und den daraus abgeleiteten Schlussfolgerungen zeigen sich kaum Veränderungen in den EBSD-OIM-Karten (Bild 7). Die Ausgangskorngrößen sind nicht betroffen und auch die Texturintensitäten scheinen sich nicht verändert zu haben. Am wichtigsten ist, dass die Gesamtentwicklung und die endgültigen Eigenschaften für beide Stähle sehr ähnlich sind. Es wird daher angenommen, dass die geringen Unterschiede in den Endeigenschaften (im direkten Vergleich beider Stähle, Bild 2-9) ein Überbleibsel der Unterschiede in den Anfangsbedingungen sind und keine weiteren Unterschiede durch die Festwalzbehandlung selbst hervorgerufen werden. Infolgedessen ist auch die Verteilung der Eigenspannungen für beide Festwalzzustände sehr ähnlich. Als Nebeneffekt ist zu berücksichtigen, dass Eigenspannungsverläufe für beide Stahlsorten entlang der Winkel $30^{\circ}$ und $15^{\circ}$ eine stärkere Tiefenwirkung aufweisen als in den übrigen Messrichtungen. Diese Beobachtung dürfte auf unterschiedliche Relativgeschwindigkeiten zwischen Werkzeug und Werkstück in der Kontaktfläche als Folge des Kurbelwellenrundungsradius $(3,5 \mathrm{~mm})$ und des Festwalzwinkels von $34,85^{\circ}$ zurückzuführen sein. Diese Faktoren führen zu einem mehrachsigen Eigenspannungszustand in der Randschicht, der primär für die Verschiebung der Übergangszone in tiefere Materialbereiche verantwortlich ist. Vor allem kann festgestellt werden, dass das Festwalzen sehr effektiv Eigenspannungen der I. Art einbringt, wie aus dem direkten Vergleich der Eigenspannungswerte und Integralbreiten der jeweiligen festgewalzten und induktionsgehärteten Zustände abgeleitet werden kann. Obwohl die Integralbreitenwerte (bzw. die Härte) in beiden induktionsgehärteten Stählen deutlich höher sind, sind die Eigenspannungen in Bezug auf die absoluten Werte und Verteilungen sehr ähnlich.

Offensichtlich sind im direkten Vergleich der beiden Stähle, d. h. $38 \mathrm{MnSiVS} 5$ und $42 \mathrm{CrMo4}$, beim Induktionshärten signifikante Unterschiede in der lokalen Eigenschaftsentwicklung zu erkennen. Die Gründe für diese offensichtlichen Unterschiede werden im weiteren Verlauf dieses Kapitels diskutiert. 
Upon induction hardening, the medium carbon microalloyed steel shows a non-uniform hardness distribution within the whole fillet area, i. e. a steady decrease of hardness within the surface volume probed. On the contrary, the $42 \mathrm{CrMo} 4 \mathrm{Q}+\mathrm{T}$ steel reveals a quite homogeneous hardness level across the scanning field until it suddenly drops at a surface distance of about $2.25 \mathrm{~mm}$ (Figs. 2e and f). In Figure 10 the continuous cooling curves are schematically depicted (for $38 \mathrm{MnSiVS} 5$ in red, for $42 \mathrm{CrMo} 4$ in yellow) revealing the minimum cooling rate required to avoid evolution of ferrite and pearlite, respectively. As follows from Figure 10, a similar microstructure (i. g. martensite and bainite) can be established resulting from quenching from austenitization level with regard to sufficiently high cooling rates used in the induction hardening process. Since the same induction hardening conditions were used, hardness inhomogeneities within the fillet region, especially for the $38 \mathrm{MnSiVS5}$, are due to non-optimal process parameters and a different initial microstructure compared to the $42 \mathrm{CrMo} 4$. This significantly affects the final microstructure evolution and, thus, the hardness distribution of the treated surface area. The results highlight that thermal treatment by induction hardening reacts more sensitively to small changes within the process compared to the mechanical treatment of deep rolling.

A local analysis of prevailing microstructural features by EBSD, KAM and ECCI, however, is shown to be very difficult in the induction hardened conditions. As it can be directly deduced from integral width values depicted in (Figs. 6e and f), lattice distortion is extremely high. Microstructural features inducing such high degree of distortion, however, are hardly resolved by EBSD and KAM due to insufficient resolution and sensitivity, respectively. ECCI results depicted in Figures $9 \mathrm{e}$ and $\mathrm{f}$ clearly resolve a very high density of defects, however, the contribution of single microstructural features still can be hardly deduced. Obviously, it can be concluded that treatment by induction hardening leads to very high contributions of micro stresses and, thus, residual stresses of II. and III. kind. As it can be deduced from the residual stress fields obtained by XRD (Figs. 5e and f), however, far reaching residual stresses of I. kind are not promoted to the same degree such that residual stresses found after deep rolling are almost as high (Figs. $5 \mathrm{c}$ and d).

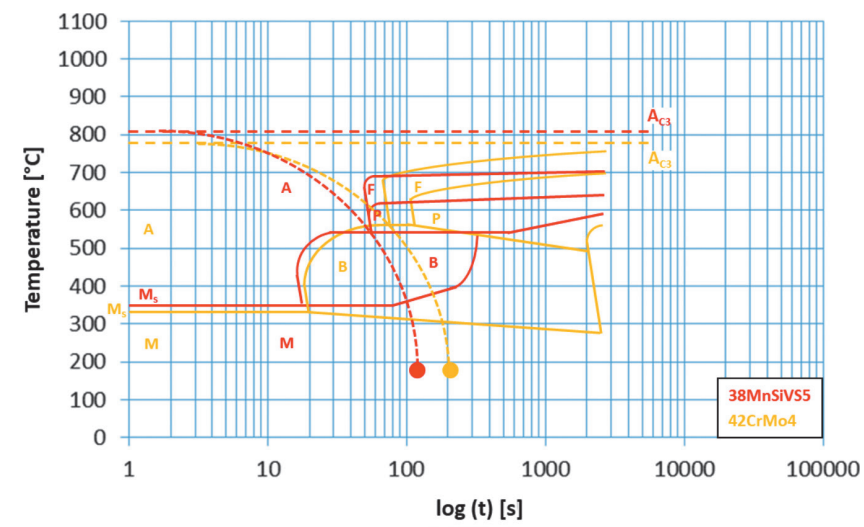

Nach der Induktionshärtung zeigt der mikrolegierte Stahl mit mittlerem Kohlenstoffgehalt eine ungleichmäßige Härteverteilung im gesamten Verrundungsbereich, d. h. eine stetige Abnahme der Härte innerhalb des untersuchten Oberflächenvolumens. Im Gegensatz dazu zeigt der 42CrMo4 Q+T-Stahl ein recht homogenes Härteniveau über das Scanfeld, bis es bei einem Oberflächenabstand von etwa 2,25 mm plötzlich abfällt (Bild 2e und 2f). In Bild 10 sind die kontinuierlichen Abkühlungskurven schematisch dargestellt (für 38MnSiVS5 in Rot, für 42CrMo4 in Gelb), die die minimale Abkühlungsrate zeigen, die erforderlich ist, um die Entwicklung von Ferrit bzw. Perlit zu vermeiden. Wie aus Bild 10 hervorgeht, kann ein ähnliches Mikrogefüge (z. B. Martensit und Bainit) durch Abschrecken auf Austenitisierungsniveau im Hinblick auf ausreichend hohe Abkühlungsraten beim Induktionshärtungsprozess erzielt werden. Da die gleichen Induktionshärtebedingungen verwendet wurden, sind Härteinhomogenitäten innerhalb des Verrundungsbereichs, insbesondere beim 38MnSiVS5, auf nicht optimale Prozessparameter und ein anderes Ausgangsgefüge im Vergleich zum 42CrMo4 zurückzuführen. Dies beeinflusst signifikant die endgültige Gefügeentwicklung und damit die Härteverteilung des behandelten Oberflächenbereichs. Die Ergebnisse verdeutlichen, dass die thermische Behandlung des Induktionshärtens im Vergleich zur mechanischen Behandlung des Festwalzens empfindlicher auf kleine Änderungen innerhalb des Prozesses reagiert.

Die lokale Analyse der vorherrschenden mikrostrukturellen Merkmale mittels EBSD, KAM und ECCI erweist sich jedoch bei den Induktionsbedingungen als sehr schwierig. Wie aus den in Bild 6 e und $6 \mathrm{f}$ dargestellten Integralbreitenwerten direkt abgeleitet werden kann, ist die Gitterverzerrung extrem hoch. Die mikrostrukturellen Merkmale, die einen solch hohen Grad an Verzerrung verursachen, werden jedoch aufgrund der unzureichenden Auflösung bzw. Empfindlichkeit durch EBSD und KAM kaum aufgelöst. Die in Bild 9e und 9f dargestellten ECCI-Ergebnisse lösen eine sehr hohe Defektdichte deutlich auf, der Beitrag einzelner mikrostruktureller Merkmale lässt sich jedoch kaum ableiten. Offensichtlich lässt sich daraus schließen, dass die Behandlung durch Induktionshärten zu sehr hohen Graden an Mikrospannungen und damit zu Eigenspannungen II. und III. Art führt. Wie aus den mittels XRD gewonnenen Eigenspannungsfeldern (Bild 5e und 5f) abgeleitet werden kann, werden jedoch weitreichende Eigenspannungen I. Art nicht in gleichem Maße gefördert, sodass die nach

Fig. 10. Schematic highlighting relevant continuous-cooling-transformation (CCT)-curves for a medium carbon 38MnSiVS5 microalloyed steel (red) and a $\mathrm{Q}+\mathrm{T} 42 \mathrm{CrMo} 4$ steel (yellow). The cooling curves depicted highlight the required minimum cooling rate to avoid evolution of ferrite and pearlite. Data recompiled from $[16,17]$

Bild 10. Schematische Darstellung der relevanten kontinuierlichen ZeitTemperatur-Umwandlungs (ZTU)-Kurven für einen mikrolegierten Stahl mit mittlerem Kohlenstoffgehalt 38MnSiVS5 (rot) und einen vergüteten Stahl $42 \mathrm{CrMo4}$ (gelb). Die dargestellten Abkühlkurven heben die erforderliche minimale Abkühlrate hervor, welche die Entwicklung von Ferrit und Perlit verhindert. Daten neu zusammengestellt aus $[16,17]$ 
Focusing on the residual stress distribution in the induction hardened fillet area in Figures 5e and f, similar compressive residual stress states can be seen. In fact, higher magnitudes and in particular more far-reaching compressive residual stress fields can be determined for the $42 \mathrm{CrMo4}$. As illustrated in the hardness results (Figs. 2e and f) and integral width profiles (Figs. 6e and f), the transition zones at $30^{\circ}$ shown in Figures $5 \mathrm{e}$ and $\mathrm{f}$ reveal the deepest impact. Basically, differences in the induced penetration depths of the compressive residual stresses as well as magnitudes are due to not specifically tailored process parameters. In order to draw further conclusions, extensive induction hardening test series on the crankshafts have to be performed.

During induction hardening, the evolution of residual stresses is considerably influenced by the martensitic phase transformation and the associated thermal dilatations. A higher penetration depth of compressive residual stress values in case of the $42 \mathrm{CrMo} 4 \mathrm{com}$ pared to the $38 \mathrm{MnSiVS} 5$ can be explained from Figures 3 and 4 . At position (3) (transition area) in Figure 3 a martensitic phase transformation cannot be seen anymore. Thus, austenitization in these areas was not achieved using the applied process parameters. This directly affects the evolution of compressive residual stress values leading to a premature reduction of the resulting penetration depth. However, in case of the $42 \mathrm{CrMo} 4$ martensitic and bainitic fractions can still be seen (position (2) in Fig. 4). In fact, martensitic and bainitic fractions are accompanied by an increased penetration depth of resulting compressive residual stress values.

In summary, the effect of a thermal surface treatment is, apart from different initial microstructures and the respective chemical composition, significantly determined by the applied process parameters. Deep rolling, on the contrary, proves to be a robust surface layer treatment regarding small differences in the initial microstructure, the chemical composition and the applied process parameters.

\section{Conclusion}

The present study examined differences in microstructural evolution upon application of established surface hardening treatments for medium carbon $38 \mathrm{MnSiVS} 5$ microalloyed steel and a $\mathrm{Q}+\mathrm{T}$ $42 \mathrm{CrMo} 4$ steel. From the results presented the following conclusions can be drawn:

- For in-depth analysis with repect to microstructural changes, high-resolution SEM-based techniques such as EBSD and ECCI have proven to be very effective for fast qualitative evaluation. Differences in the residual stresses and integral widths profiles found can, eventually, be attributed to elementary microstructur- dem Festwalzen gefundenen Eigenspannungen fast ebenso ausgeprägt sind (Bild $5 \mathrm{c}$ und $5 \mathrm{~d}$ ).

Betrachtet man die Eigenspannungsverteilung im Bereich der induktiv gehärteten Hohlkehle in Bild 5e und 5f, so sind ähnliche Druckeigenspannungszustände zu erkennen. Tatsächlich lassen sich für $42 \mathrm{CrMo} 4$ höhere Beträge und vor allem weitreichendere Druckeigenspannungsfelder feststellen. Wie in den Härteergebnissen (Bild 2e und 2f) und Integralbreitenprofilen (Bild 6e und 6f) dargestellt, zeigen die in Bild 5e und $5 f$ gezeigten Übergangszonen bei $30^{\circ}$ den tiefsten Einschlag. Grundsätzlich sind die Unterschiede in den induzierten Eindringtiefen der Druckeigenspannungswerte sowie die Größenordnungen auf nicht optimal abgestimmte Prozessparameter zurückzuführen. Um weitere verlässliche Aussagen treffen zu können, müssen umfangreiche Induktionshärtungsversuchsreihen an Kurbelwellenserien durchgeführt werden.

Während des Induktionshärtens wird die Entwicklung der Eigenspannungen maßgeblich durch die martensitische Phasenumwandlung und die damit verbundenen thermischen Ausdehnungen beeinflusst. Eine höhere Eindringtiefe der Druckeigenspannungswerte im Falle des 42CrMo4 im Vergleich zum 38MnSiVS5 lässt sich anhand von Bild 3 und 4 erklären. An der Position (3) (Übergangsbereich) in Bild 3 ist eine martensitische Phasenumwandlung nicht mehr zu erkennen. Eine Austenitisierung in diesen Bereichen wurde also bei den verwendeten Prozessparametern nicht erreicht. Dies wirkt sich direkt auf die Entwicklung der Druckeigenspannungswerte aus und führt zu einer vorzeitigen Reduzierung der resultierenden Eindringtiefe. Im Falle des $42 \mathrm{CrMo} 4$ sind jedoch noch martensitische und bainitische Anteile zu sehen (Position (2) in Bild 4). Tatsächlich gehen martensitische und bainitische Anteile mit einer erhöhten Eindringtiefe der resultierenden Druckeigenspannungswerte einher.

Zusammenfassend lässt sich sagen, dass die Wirkung einer thermischen Oberflächenbehandlung neben unterschiedlichen Ausgangsgefügen und der jeweiligen chemischen Zusammensetzung maßgeblich durch die angewandten Prozessparameter bestimmt wird. Das Festwalzen hingegen erweist sich als robuste Randschichtbehandlung bezüglich geringer Unterschiede im Ausgangsgefüge, der chemischen Zusammensetzung und der angewandten Prozessparameter.

\section{Schlussfolgerung}

Die vorliegende Studie untersuchte Unterschiede in der Gefügeentwicklung nach Anwendung etablierter Oberflächenhärtungsbehandlungen für einen mikrolegierten Stahl mit mittlerem Kohlenstoffgehalt (38MnSiVS5) und einen Q+T-Stahl (42CrMo4). Aus den vorgestellten Ergebnissen können die folgenden Schlussfolgerungen gezogen werden:

- Für eine tiefgreifende Analyse in Bezug auf mikrostrukturelle Veränderungen haben sich hochauflösende REM-basierte Techniken wie EBSD und ECCI für eine schnelle qualitative Auswertung als sehr effektiv erwiesen. Unterschiede in den gefundenen Eigenspannungs- und Integralbreitenprofilen lassen sich letztlich auf 
al features being the basis for the determination of those values as they reflect internal component stresses on different scales.

- Through a direct comparison of hardness and integral width values upon induction hardening and deep rolling, major differences between the medium carbon $38 \mathrm{MnSiVS} 5$ microalloyed steel and the $\mathrm{Q}+\mathrm{T} 42 \mathrm{CrMo} 4$ steel can only be seen in case of the thermal surface treatment. The mechanical treatment no significant differences can be derived.

- Residual stress profiles induced by the applied deep rolling and induction hardening treatments show only slight differences in terms of the magnitude and the course itself.

- Deep rolling in contrast to induction hardening proves to be a less sensitive surface layer treatment with respect to small differences in the initial microstructure, the chemical composition and the applied process parameters.

\section{Acknowledgements}

The authors gratefully acknowledge funding from the EC Research Fund for Coal and Steel, RFCS, for the project Stiffcrank, no. 754155

\section{References}

1. Tisza, M.; Czinege, I.: Comparative study of the application of steels and aluminium in lightweight production of automotive parts. Int. J. Lightweight Mat. Manuf. 1 (2018) 4, pp. 229-238, DOI:10.1016/j.ijlmm.2018.09.001

2. Matlock, D. K.; Alogab, K. A.; Richards, M. D.; Speer, J. G.: Surface processing to improve the fatigue resistance of advanced bar steels for automotive applications. Mat. Research 8 (2005) 4, pp. 453-459, DOI:10.1590/S1516-14392005000400017

3. Citti, P.; Giorgetti, A.; Millefanti, U.: Current challenges in material choice for highperformance engine crankshaft. Proc. Struct. Integ. 8 (2018), pp. 486-500, DOI:10.1016/j.prostr.2017.12.048

4. Savaria, V.; Monajati, H.; Bridier, F.; Bocher, P.: Measurement and correction of residual stress gradients in aeronautical gears after various induction surface hardening treatments. J. Mat. Processing Techn. 220 (2015), pp. 113-123, DOI:10.1016/j.jmatprotec.2014.12.009

5. Witek, L.; Sikora, M.; Stachowicz, F.; Trzepiecinski, T.: Stress and failure analysis of the crankshaft of diesel engine. Eng. Failure Analysis 82 (2017), pp. 703-712, DOI:10.1016/j.engfailanal.2017.06.001

6. Fischer, A.; Scholtes, B.; Niendorf, T.: On the influence of surface hardening treatments on microstructure evolution and residual stress in microalloyed medium carbon. JMEP J. of Mat. Eng. Perform. 29 (2020) 4, pp. 3040-3054, DOI:10.1007/ s11665-020-04866-y

7. Garcia, F: Crankshaft Fillet Hardening: Challenges and Prospects. Industrial Heating 82 (2014) 8, pp. 47-48

8. Coupard, D.; Palin-luc, T.; Bristiel, P.; Ji, V.; Dumas, C.: Residual stresses in surface induction hardening of steels - Comparison between experiment and simulation. Mat. Sc. Eng. A 487 (2008) 1-2, pp. 328-339, DOI:10.1016/j.msea.2007.10.047

9. Delgado, P.; Cuesta, I. I.; Alegre, J. M.; Díaz, A.: State of the art of Deep Rolling. Precision Eng. 46 (2016), pp. 1-10, DOI:10.1016/j.precisioneng.2016.05.001

10. Citti, P.; Giorgetti, A.; Millefanti, U.: Mechanical characterization of a new low carbon bainitic steel for high performance crankshaft. Proc. Struct. Integ. 12 (2018), pp. 438-447, DOI:10.1016/j.prostr.2018.11.074 elementare mikrostrukturelle Merkmale zurückführen, die zur Bestimmung dieser Werte herangezogen werden, da sie BauteilEigenspannungen auf unterschiedlichen Skalen widerspiegeln.

- Beim direkten Vergleich der Härte- und Integralbreitenwerte nach dem Induktionshärten und Festwalzen sind große Unterschiede zwischen dem mittelkohlenstoffhaltigen mikrolegierten Stahl 38MnSiVS5 und dem Stahl Q+T 42CrMo4 nur durch die thermische Oberflächenbehandlung zu erkennen. Im Falle der mechanischen Behandlung lassen sich keine signifikanten Unterschiede feststellen.

- Eigenspannungsprofile, die durch die angewandten Behandlungen Festwalzen und Induktionshärten induziert werden, zeigen nur geringe Unterschiede in Bezug auf die Größe und den Verlauf selbst.

- Das Festwalzen erweist sich im Gegensatz zum Induktionshärten als unempfindlichere Randschichtbehandlung gegenüber geringen Unterschieden im Ausgangsgefüge, der chemischen Zusammensetzung und den angewandten Prozessparametern.

\section{Danksagung}

Die Autoren bedanken sich für die Förderung durch den EG-Forschungsfonds für Kohle und Stahl, RFCS, für das Projekt Stiffcrank, Nr. 754155.
11. Giorgetti, A.; Cavallini, C.; Arcidiacono, G.; Citti, P.: A Mixed C-VIKOR Fuzzy Approach for Material Selection during Design Phase: A Case Study in Valve Seats for High Performance Engin. Int. J. Applied Eng. Res. (2017) 12, pp. 3117-3129

12. Singh, P.; Batra, U.; Sangal, S.: Fracture Toughness Behavior of $38 \mathrm{MnSiVS5}$ Microalloyed Steel After Isothermal Transformation and Thermomechanical Processing. Mat. Today: Proc. 4 (2017) 8, pp. 8528-8537, DOI:10.1016/j.matpr. 2017.07.199

13. Kreethi, R.; Mondal, A. K.; Dutta, K.: Ratcheting fatigue behaviour of 42CrMo4 steel under different heat treatment conditions. Mat. Sc. Eng. A 679 (2017), pp. 66-74, DOI:10.1016/j.msea.2016.10.019

14. Singh, P.; Batra, U.; Sanga, S.: Structural Evolution During Isothermal Transformation and Thermomechanical Processing of Medium Carbon Microalloyed Steel. COM, Annual Conference of Metallurgists of CIM, 45. 01.-04.10.2006, Montréal, J. A. Szpunar, CIM, Montréal, 2006, pp. 131-142

15. Wegner, K.-W.: Werkstoffentwicklung für Schmiedeteile im Automobilbau. ATZ Automobiltechnische Zeitschrift 100 (1998) 12, pp. 918-927

16. Wu, H.; Liu, C.; Zhao, Z.; Zhao, Y.; Zhu, S.; Liu, Y.; Bhole, S.: Design of air-cooled bainitic microalloyed steel for a heavy truck front axle beam. Mat. \& Design 27 (2006) 8, pp. 651-656, DOI:10.1016/j.matdes.2004.12.014

17. Walton, H. W.; Wallis, R. A.: Heat treating: Proceedings of the $18^{\text {th }}$ conference; including the Liu Dai Memorial Symposium, 12.-15.10.1998. ASM International, Materials Park, OH, 1999. - ISBN: 978-0871706263

18. DIN EN ISO 6507-1:2018-07: Metallische Werkstoffe - Härteprüfung nach Vickers - Teil 1 Prüfverfahren. Beuth Verlag, Berlin, 2018

19. Savaria, V.; Bridier, F.; Bocher, P.: Computational quantification and correction of the errors induced by layer removal for subsurface residual stress measurements. Int. J. Mech. Sc. 64 (2012) 1, pp. 184-195, DOI:10.1016/j.ijmecsci.2012.07.003

20. Macherauch, E.; Wohlfahrt, H.; Wolfstieg, U.: Zur zweckmäßigen Definition von Eigenspannungen. HTM J. Heat Treat. Mat. 28 (1973) 3, pp. 201-211 
21. Scardi, P.; Leoni, M.; Delhez, R.: Line broadening analysis using integral breadth methods: a critical review. J. of Applied Crystallography 37 (2004) 3, pp. 381-390, DOI:10.1107/S0021889804004583

22. Stüdemann, H.; Brundiek, H.: Vergleich von Härten, Anlassen, Warmbadhärten und Unterkühlen in ihrem Einfluß auf die technologischen Eigenschaften des Stahles X 40 Cr 13. Westdeutscher Verlag, Köln, 1967. - ISBN: 978-3-663-03963-1

23. Läpple, V: Wärmebehandlung des Stahls: Grundlagen, Verfahren und Werkstoffe, 11. Aufl., Verlag Europa Lehrmittel, Haan, 2014. - ISBN: 978-3-8085-1829-8

24. Çevik, G.; Gürbüz, R.: Evaluation of fatigue performance of a fillet rolled diesel engine crankshaft. Eng. Failure Analysis 27 (2013), pp. 250-261, DOI:10.1016/j. engfailanal.2012.07.026

25. Lange, K.; Liewald, M.: Umformtechnik Handbuch für Industrie und Wissenschaft: Band 2: Massivumformung. Springer, Berlin, Heidelberg, 1988. - ISBN: 978-3540177098
26. Hajyheydari, E.; Liewald, M.; Felde, A.: Technologische Eigenschaften von AFPStahl im Temperaturbereich zwischen Raumtemperatur und $500^{\circ} \mathrm{C}$. SchmiedeJOURNAL (2012), pp. 54-57

27. Hahn, F: Werkstofftechnik-Praktikum: Werkstoffe prüfen und verstehen. Hanser, München, 2015. - ISBN: 978-3-446-43258-1

\section{Bibliography}

DOI:10.1515/htm-2021-0002

HTM J. Heat Treatm. Mat.

76 (2021) 3; page 175-194

(C) 2021 Walter de Gruyter GmbH, Berlin/Boston, Germany ISSN 1867-2493, e-ISSN 2194-1831 